\title{
As “Observações sobre luz e cores" (1756) de Thomas Melvill (1723-1756):
} tradução comentada ${ }^{+}$

Breno Arsioli Moura ${ }^{1}$

Universidade Federal do ABC

Santo André - SP

\section{Resumo}

Neste artigo, apresento uma tradução comentada do ensaio “Observações sobre luz e cores”, escrito por Thomas Melvill (17261753). Embora atualmente desconhecido nos dias atuais, o texto é um autêntico retrato da óptica nesse século, incorporando temas, controvérsias e novas perspectivas de estudo decorrentes do legado de Isaac Newton (1642-1727) na Grã-Bretanha. É primeira vez que um texto desse autor é traduzido ao português.

Palavras-chave: Thomas Melvill; Óptica; Newton; Luz; Século XVIII.

\begin{abstract}
In this paper, I present a commented translation to Portuguese of the essay "Observations on light and colours", written by Thomas Melvill (1726-1753). Although almost unknown nowadays, the essay is a representation of the optics in this century, including themes, controversies and new perspectives of studies from Isaac Newton's (1642-1727) legacy in Britain. This is the first time that one of Melvill's essays is translated to Portuguese.
\end{abstract}

Keywords: Thomas Melvill; Optics; Newton; Light; Eighteenth Century.

\footnotetext{
+ Thomas Melvill's “Observations on light and colours": a commented translation

* Recebido: maio de 2020. Aceito: setembro de 2020.

${ }^{1}$ E-mail: breno.moura@ufabc.edu.br
} 


\section{Introdução}

A ascensão de novos pressupostos e parâmetros historiográficos a partir da metade do século XX trouxe um conjunto de reinterpretações sobre diversos aspectos e episódios da história da ciência. Foi assim, por exemplo, com a Idade Média (LE GOFF, 2014), não mais considerada um período de trevas e ignorância; com a emergência do papel e importância das mulheres na ciência (WHITEHEAD, 1999; SCHIEBINGER, 2008); ou mesmo com a ressignificação de episódios históricos clássicos, como a maçã de Isaac Newton (1642-1727) (MARTINS, 2006) ou o experimento da pipa de Benjamin Franklin (1706-1790) (COHEN, 1990; MOURA, 2019). Essa mudança de visão tem se tornado fundamental para fomentar um aprendizado mais adequado da natureza da ciência $(\mathrm{NdC})$ e dos elementos que norteiam a produção do conhecimento científico (MARTINS, 2015).

Tratando especificamente da história da óptica, dezenas de estudos realizados a partir das décadas de 1950 e 1960 têm mostrado como essa é uma área diversa, dinâmica e profícua para entendermos e discutirmos questões da $\mathrm{NdC}$. Embora nem todos especialmente voltados para o ensino, estudos históricos denotam um cenário muito mais complexo e rico que simplesmente aquele habitado pela ideia de "teoria corpuscular vs. teoria ondulatória" (STEFFENS, 1977; CANTOR, 1983; DARRIGOL, 2012; MOURA, 2016). Ainda que hoje a óptica seja relegada frequentemente a um ramo do eletromagnetismo, sua história é muito mais antiga e recheada de eventos fundamentais para o desenvolvimento da ciência moderna que sua "área mãe" dos dias atuais.

A emergência dessa nova historiografia tem sido importante, ainda, para ressaltar e discutir nomes que, por vários motivos, desapareceram dos recortes historiográficos anteriores. Esse é o caso de Thomas Melvill (1726-1753), filósofo natural escocês que trouxe importantes contribuições para a óptica no século XVIII, seja por introduzir conceitos, ideias e observações novas, seja por questionar alguns parâmetros vigentes em sua época. Melvill nasceu em Fife, Escócia filho do reverendo Andrew Melvill (m. 1736). Pelos registros na Universidade de Glasgow (Fig. 1), sabemos que ele se graduou como Master of Arts em 1744 e teve um irmão mais velho chamado Robert Melvill (1723-1809). Alguns anos depois, trabalhou com o professor de astronomia na universidade, Alexander Wilson (1714-1786), na tentativa de determinar a temperatura em altas altitudes, empinando pipas com termômetros amarrados a elas. Aparentemente, eles se tornaram colaboradores próximos, trocando cartas até 1753 (WILSON, 1829, p. 5-8). De acordo com Emerson (1981, p. 157), Melvill se tornou um membro ativo da Philosophical Society of Edinburgh, apresentando aos seus membros ao menos quatro trabalhos entre 1751 e 1753. No final desse último ano, Melvill morreu em Genebra, aos 27 anos, sob circunstâncias ainda desconhecidas. 
781 THOMAS MELVILL Andreæ F. V.D M. in Monymeal in Fife

M.A. 1744. Experimental Philosopher. Died at Geneva, December, 1753, aged 27. Brother of 655 .

Fig. 1 - Registro sobre Melvill no livro de matrículas da Universidade de Glasgow. Fonte: Addison (1913, p. 23).

Em sua curta carreira na filosofia natural, Melvill teve dois trabalhos publicados, ambos sobre luz e cores: duas cartas ao astrônomo James Bradley (1693-1762), lidas na Royal Society de Londres em Março de 1753 e publicadas nas Philosophical Transactions no mesmo ano (MELVILL, 1753-1754) ${ }^{2}$ e o ensaio "Observations on light and colours" (Observações sobre luz e cores), lido na Philosophical Society of Edinburgh em 1752, mas publicado postumamente em 1756 (MELVILL, 1756) ${ }^{3}$. No século XVIII, o trabalho de Melvill foi reconhecido a ponto de figurar entre as pessoas que mais se distinguiram pelas descobertas sobre luz e cores no livro The History and Present State of Discoveries Relating to Vision, Light and Colours (A História e o Presente Estado das Descobertas relacionadas à Visão, Luz e Cores), escrito por Joseph Priestley (1733-1804) e publicado em 1772 (MOURA, 2018, p. 165). Outros textos ou artigos sobre história da óptica publicados no século XVIII ou no início do século XIX também mencionam seus trabalhos (HUTTON, 1795; ROBISON, 1797; NICHOLSON, 1809), o que reforça a importância de Melvill para a época, embora tenha sido esquecido a partir do século seguinte.

Neste artigo, apresento uma tradução comentada das "Observações sobre luz e cores" - a partir daqui, "Observações" (MELVILL, 1756) ${ }^{4}$. O texto foi dividido em oito tópicos, abordando diferentes assuntos da óptica: (1) a penetração mútua da luz, (2) o aquecimento de corpos pela luz; (3) a aparência prateada de gotas d'água; (4) as mudanças nas cores dos corpos sob luzes de diferentes cores; (5) a teoria da luz de Leonhard Euler (1707-1783), (6) a causa da diferente refrangibilidade da luz, (7) a inflexão da luz (difração, em linguagem atual) e (8) questões, dúvidas e conjecturas sobre a luz e as cores.

As "Observações" de Melvill são o puro reflexo da óptica do século XVIII. Por uma perspectiva, o texto abordou alguns dos principais assuntos sobre luz e cores desse período, tais como a corpuscularidade da luz e sua relação com outros fenômenos naturais, como o

\footnotetext{
${ }^{2}$ Melvill escreveu uma terceira carta a Bradley, que foi publicada apenas em 1832 (BRADLEY, 1832), embora fosse conhecida entre os filósofos naturais da época.

${ }^{3}$ Dois biógrafos de Melvill (CLERKE, 2004; NORTH, 1981) afirmaram erroneamente que o ensaio foi lido na Medical Society de Edinburgo, atualmente denominada Royal Medical Society. Em contato eletrônico com a sociedade, houve a confirmação de que não há registros de Melvill em seus arquivos. Portanto, o texto foi lido apenas na Philosophical Society, como afirmado em Emerson (1981).

${ }^{4}$ Extratos das "Observações" foram publicados também no volume 25 da London Magazine no mesmo ano de 1756 e na The Gentleman's Magazine no ano seguinte.
} 
calor (tópicos 1 e 2). Defensor das teorias newtonianas, em diversas partes de seu texto Melvill citou o Óptica (NEWTON, 1996). Além disso, também trouxe descrições sobre fenômenos aparentemente novos, que posteriormente seriam associados à área de espectroscopia (tópico 4). Em outra perspectiva, Melvill buscou adicionar e aprimorar conceitos à amplamente aceita concepção corpuscular da luz, ao aventar uma lei para a repulsão (tópico 3) e ao procurar corrigir pontos que considerava falhos ou incompletos na óptica newtoniana (tópicos 6 e 7). Por fim, assim como outros defensores de Newton, Melvill contra-argumentou as críticas de objetores à concepção corpuscular, como Euler (tópico 6). Nas "Questões" que encerram o texto (tópico 8), é possível notar como Melvill reconheceu vários aspectos problemáticos da concepção corpuscular, embora não duvidasse de sua validade para explicar os mais variados fenômenos ópticos. Ler seu trabalho certamente afasta a ideia de que o século XVIII foi um período "infértil" para a óptica, bem como amplia a visão sobre o famoso - mas, supervalorizado - "debate" entre concepções corpusculares e ondulatórias (CANTOR, 1983; MOURA, 2016).

A tradução foi baseada em Melvill (1756). O original pode ser facilmente encontrado em bancos de dados virtuais. A tradução buscou seguir princípios básicos desse ofício (OUSTINOFF, 2011; RICEUR, 2011), levando em conta a adequação de termos, estrutura e coesão das frases para o português brasileiro. Apresenta-se, assim, ao leitor desse periódico, uma versão mais próxima possível do texto de Melvill para nossa língua materna. Notas de rodapé com comentários foram inseridas convenientemente, sempre com a indicação [N.T.], bem como termos entre colchetes no próprio texto, a fim de facilitar a leitura e o entendimento dos argumentos colocados pelo filósofo natural escocês. Notas do texto original também foram traduzidas, indicadas por [M.]. Caso o leitor queira acompanhar a tradução com o original, as páginas deste último foram inseridas entre colchetes ao longo da tradução.

\title{
II. Tradução comentada
}

\author{
[p. 12] \\ Artigo IV \\ Observações sobre luz e cores, por THOMAS MELVILL M. A. ${ }^{5}$ \\ Seção I \\ Da mútua penetração da luz
}

\footnotetext{
5 [M., nota do editor] Lido em 3 de janeiro e 7 de fevereiro de 1752. Tivesse o autor desse artigo (que morreu em dezembro de 1753, aos 27 anos) vivido para colocar nele seu toque final, ele teria, provavelmente, adicionado muitas coisas, e talvez reduzido algumas outras, pelo qual teria conferido ainda mais merecida aprovação do público. O Sr. Melvill costumava observar que, de todas as descobertas de Sir Isaac Newton, aquelas relacionadas à luz e às cores fossem talvez as mais curiosas. Foi, de certa maneira, fora do comum que poucos, se algum, de seus seguidores tenham dado um passo além dele nesses assuntos ou tentado completar o que ele deixou inacabado. Nosso autor [Melvill], portanto, propôs a se dedicar particularmente a novas discussões sobre a teoria de luz e cores. O ensaio seguinte é uma amostra do que teria sido esperado dele, e mostra suficientemente a genialidade incomum de seu autor.
} 
1. Uma das primeiras grandes dificuldades que surgem ao refletirmos sobre esse assunto é conceber como é possível que a [p. 13] luz possa se mover através da luz em todas as direções imagináveis, sem ocasionar a menor confusão ou desvio perceptível de seu curso retilíneo. ${ }^{6}$ A partir dessa questão, muitos têm sido induzidos a acreditar que [a luz] é incorpórea, e todos que ponderaram inteiramente essa dificuldade têm visto a necessidade de atribuir a ela uma sutileza incomparavelmente maior [que aquela] que somos levados a atribuir, por quaisquer fenômenos, a outros tipos de corpos na Natureza. Não há qualquer ponto físico no horizonte visível que não transmita raios a qualquer outro ponto, nenhuma estrela no céu que não emita raios a qualquer outra estrela. A totalidade do horizonte está preenchida com uma esfera de raios de qualquer ponto nele e a totalidade do universo visível [está preenchida] com uma esfera de raios de cada estrela. Em suma, para qualquer coisa que sabemos, há raios de luz unindo cada dois pontos físicos no universo, e isso em direções contrárias, exceto quando corpos opacos intervêm.

2. Aqueles que supõem que a luz não é nada mais que vibrações ou pulsos propagados através de um meio elástico sutil a partir do objeto visível até o olho, podem, talvez, eliminar a dificuldade [de explicar os fenômenos ópticos por meio dessa teoria] ao atribuir uma pequenez suficiente [p. 14] às partículas daquele meio, uma vez que vemos, por experiência, que som no ar e ondas na água são transmitidos em diferentes direções, sem se interferirem sensivelmente. Mas, como essa hipótese parece insustentável em outros relatos, devemos nos esforçar para acomodar nossa solução à única concepção que podemos conceber disso, a saber, aquela de partículas [sendo] na verdade projetadas dos corpos luminosos.

3. É manifesto que, embora a mera sutileza das partículas de luz possa servir para explicar sua fácil passagem através de corpos densos transparentes, em todas as direções, ela não serve para explicar sua fácil passagem através de outra luz igualmente sutil. Do contrário, para esse propósito, parece ser necessário supor [ser] a luz incomparavelmente rarefeita quando em [meios] mais densos. Ou seja, que os semidiâmetros de duas das partículas mais próximas no mesmo ou em diferentes raios são incomparavelmente menores que suas distâncias [uma para a outra], logo após suas emissões [dos corpos luminosos]. ${ }^{7}$

4. Vamos considerar brevemente o curso de uma partícula de luz ao olho humano a partir de qualquer das estrelas [p. 15] fixas mais remotas, por exemplo, a partir

\footnotetext{
${ }^{6}$ [N.T.] Nos séculos XVII e XVIII, essa crítica era comum entre os objetores da concepção corpuscular. A resposta mais usual dos seus defensores era de que a luz era formada por corpúsculos muito diminutos, o que diminuía as chances de choque entre eles. Para mais detalhes, ver Cantor (1983, p. 52-59).

7 [N.T.] Com esse trecho, Melvill adicionou mais um argumento favorável à concepção corpuscular: os corpúsculos de luz não era somente diminutos, mas a distância entre eles em um mesmo raio seria muito grande em comparação aos seus tamanhos.
} 
daquela pequena chamada $\operatorname{Rider}^{8}$ na cauda da Ursa Maior. As partículas pelas quais nós vemos aquela estrela passaram, em primeiro lugar, através do espaço ao redor dela, no qual há provavelmente vários planetas orbitando e que deve estar, assim, tão preenchido com uma esfera de raios de cada um deles [planetas] que eles podem ser visíveis a um olho situado em qualquer lugar nesses espaços. Depois disso, elas [as partículas] passaram lateralmente através de toda a torrente de luz fluindo da estrela de segunda magnitude que vemos atrás dela. ${ }^{9} \mathrm{E}$, por último, elas passaram da mesma maneira através de todo o oceano de luz solar e de toda aquela luz de todos os cometas, planetas e satélites com a qual o espaço ao redor do Sol é preenchido. Além disso, em cada ponto físico de suas numerosas jornadas de Rider até nosso olho, elas passaram através de raios de luz de cada estrela no universo visível fluindo em todas as direções. Mesmo assim, durante todo [o caminho], elas nunca colidiram contra uma partícula de luz, do contrário não poderiam ter vindo nas suas verdadeiras direções ao nosso olho. Essa consideração não pode se furtar em sugerir uma noção geral da raridade e [p. 16] tenuidade da luz, superando muito todas as suposições que são frequentemente feitas sobre ela.

5. A chance pela qual qualquer corpo tem de se chocar com outros de magnitude similar é diminuída em proporção ao volume dos corpos em relação ao espaço em que eles se movem. Deve ser suposto, consequentemente, como mencionamos acima, que a distância das partículas mais próximas fluindo na mesma e em diferentes linhas deve exceder seus diâmetros, não infinitamente, mas um número de vezes absolutamente incomparável com todos nossos números comuns, tal que uma partícula possa escapar em um ponto físico de seu curso. No entanto, para que ela possa passar livremente através de toda a distância das estrelas fixas mais remotas [até nós], é evidente que essa proporção de excesso deve ser multiplicada por um número novamente incomparável. Mas esse excesso, assim aumentado, deve ser elevado a uma potência cujo exponente é um número igual ao número de todas as estrelas fixas, planetas e cometas. Por último, se há um meio elástico difundido através do espaço mundano, como a propagação do calor ${ }^{10}, 11$ e muitos outros fenômenos parece insinuar, esse último número pode ser, pelo menos, dobrado, se nós [p. 17] expressássemos a proporção na qual a distância dos raios mais próximos excedem o diâmetro de suas partículas. Ainda assim, essa distância dos raios mais próximos,

\footnotetext{
8 [N.T.] Referência à estrela Alcor, na cauda da Ursa Maior.

9 [N.T.] Provavelmente, uma referência à estrela Mizar, também conhecida como Horse, que acompanha Alcor. 10 [M.] Óptica de Newton, Questões, perto do fim.

11 [N.T.] Possivelmente, Melvill se refere à Questão 29, em que Newton abordou a interação entre os raios de luz e os corpos. Ver Newton (1996, p. 271).
} 
fluindo do mesmo centro, é tão incomparavelmente abaixo de nossas menores medidas que não há possibilidade de defini-la. ${ }^{12}$

6. Tivesse Euler considerado essa extrema rarefação da luz, assim como sua tenuidade, a qual deve ser reconhecida por todos que supõem que suas partículas são realmente projetadas a partir dos corpos lúcidos, ele não teria alegado que esse conceito [a corpuscularidade da luz] é inconsistente com a liberdade e perpetuidade dos movimentos celestes. ${ }^{13}, 14$

7. Alguns têm pensado ${ }^{15}$ que, se as partículas de luz repelem umas às outras, suas perturbações mútuas podem ser evitadas. Mas, o contrário se manifesta na mínima reflexão, pois, embora, por aquele modo [a repulsão], seja possível evitar que elas colidam, elas devem instantaneamente se desviar de seus cursos retilíneos em diferentes direções, assim que elas entrarem na região de seus poderes mútuos. Dessa forma, encontramos pela experiência que é impossível fazer uma corrente de ar penetrar em outra sem confusão, pois as duas correntes ou se unem em uma [corrente] comum com [p. 18] uma direção intermediária ou produzem redemoinhos irregulares. ${ }^{16}$

8. Aqui, a propósito, vemos que o engenhoso sistema de Boscovich, professor Romano, acerca dos elementos da matéria, ${ }^{17}$ o que quer que possa ser dito em outras considerações, não nos ajuda a compreender a mútua penetração da luz, pois, pontos indivisíveis dotados com um poder repulsivo insuperável e limitado a uma distância finita estão tão sujeitos a interferir [no curso de outros corpos] quanto partículas sólidas de magnitude finita.

12 [N.T.] Nota-se que Melvill não apresentou qualquer fundamento para esse argumento, tampouco cálculos mais explícitos. Conclui-se que ele os colocou simplesmente para ressaltar o enorme espaço entre duas partículas de luz sucessivas, sem, contudo, se propor a detalhá-los.

13 [M.] Veja sua Nova theoria lucis et colorum.

14 [N.T.] Nesse trabalho, publicado em 1746, Euler apresentou uma teoria ondulatória para a luz, além de críticas à concepção corpuscular, então defendida pelos seguidores de Newton no século XVIII. Para mais detalhes, ver Hakfoort (1995).

15 [N.T.] Melvill provavelmente se refere a Roger Boscovich (1711-1787), que na época propôs que a matéria poderia ser reduzida a pontos, com forças de atração e repulsão alternadas ao redor. Suas ideias foram consideravelmente populares dentre os defensores da concepção corpuscular para a luz no século XVIII. Para mais detalhes, consultar Guzzardi (2017). Essa sugestão é corroborada pela menção explícita a Boscovich no item seguinte.

16 [N.T.] Portanto, segundo Melvill, haveria uma sensível confusão quando dois raios de luz se cruzassem, uma vez que, ao se repelirem, eles mudariam suas trajetórias.

17 [M.] Veja sua Dissertatio de lumine et de viribus vivis. 


\section{Seção II}

Do aquecimento de corpos pela luz

9. Parece, pelos experimentos de Sir Isaac Newton sobre inflexão [difração] da luz, que corpos agem sobre ela a alguma distância e que esse mesmo poder, exercido variadamente em variadas circunstâncias, é a causa, também, da refração e da reflexão. Não sabemos de nenhum caso de qualquer tipo de atração ou repulsão na Natureza que não seja mútuo. Observamos, igualmente, que corpos são aquecidos pela influência dos raios do Sol. É, portanto [p. 19], natural considerarmos isso como o efeito da refração da luz sobre os corpos, e isso a uma distância deles. Pois, não há razão para pensar que a luz produz calor por colidir de fato com as partes sólidas dos corpos, uma vez que estamos convencidos que corpos produzem a reflexão e a refração da luz sem as sofrerem [reflexão e refração] ao entrar em contato com elas [partículas dos corpos]. ${ }^{18}$

10. Desses princípios segue que a luz, ao passar de um meio para outro de diferente densidade, deve sempre produzir algum grau de calor, porque é parcialmente refratada e refletida na superfície comum [entre os dois meios]. Em segundo lugar, ao passar através do mesmo meio transparente homogêneo ou perfeitamente transparente, ela não pode produzir nenhum calor, uma vez que não há reflexão ou refração e nenhuma influência do corpo sobre a luz. Não obstante, [nessa situação] todo raio segue em seu próprio curso retilíneo, como se se movessem em um vazio perfeito. ${ }^{19,} 20$

11. Disso, torna-se aparente que na água, no vidro ou em outros meios transparentes que [p. 20] são aquecidos pelos raios do Sol, o calor deve ser propagado de suas superfícies em direção às suas partes centrais. ${ }^{21}$

12. Consequentemente, da mesma forma, entendemos porque corpos opacos são aquecidos mais rapidamente pelos raios solares que os transparentes, visto que há inúmeras reflexões e refrações dentro de suas substâncias, além do que acontece em comum com corpos transparentes em suas partes superficiais. Como cada partícula colorífica de um corpo opaco, pela reação das partículas de luz, deve ser de alguma

\footnotetext{
18 [N.T.] Melvill possivelmente se inspirou nas proposições 8 e 9 do Livro II do Óptica, utilizando termos muito semelhantes aos empregados por Newton (NEWTON 1996, p. 199-203). Nessas proposições, Newton contrapôs a ideia de que a reflexão seria causada pelo choque da luz com os corpos. Ele propôs que esse fenômeno, além da refração, fosse causado por algum tipo de poder de curto alcance exercido dos corpos sobre os raios de luz.

19 [M.] Sir Isaac Newton, no terceiro livro de seus Principia, onde ele discute as caudas de cometas, estabelece isso como um princípio óbvio: Quod radii solis non agitant media qua permanant, nisi in reflexione et refractione.

20 [N.T.] Melvill fez referência ao trecho em Newton (1848, p. 492).

21 [M.] Eu encontrei, por repetidas tentativas, que o calor da água em lagos profundos decresce regularmente a partir da superfície para baixo.
} 
maneira movida quando a luz é refletida para trás e para frente entre as mesmas partículas, é evidente que elas [as partículas dos corpos] devem ser empurradas para trás e para frente com um movimento vibratório. O tempo de uma vibração será igual àquele que a luz leva ao se mover entre uma partícula ou a partir de uma partícula de um corpo para outra próxima. Essa distância na maioria dos corpos sólidos opacos não pode ser suposta maior que $\frac{1}{12500}$ de uma polegada, que é [p. 21] o espaço que uma partícula de luz descreve em $\frac{1}{125000000000000}$ partes de um segundo ${ }^{22}$. Com um movimento tão rápido as partes internas dos corpos podem então ser agitadas pela influência da luz, de modo a realizar 125000000000000 vibrações ou mais em um segundo de tempo! A chegada de diferentes partículas de luz em um mesmo ou em diferentes raios na superfície de uma mesma partícula colorífica pode perturbar a regularidade de suas vibrações, mas evidentemente aumentará a frequência delas ou provocará vibrações ainda mais minúsculas entre as partes que compõem essas partículas, meios pelos quais o movimento interno se torna mais sutil e completamente difundido. Se a quantidade de luz admitida no corpo for aumentada, as vibrações das partículas devem da mesma forma aumentar em magnitude e velocidade, até que, no fim, se tornem tão violentas a ponto de fazer com que todas as partículas componentes se quebrem em pedaços pelas suas colisões mútuas, situação na qual a cor e a textura do corpo deve ser destruída. Assim, podemos imaginar, a partir de princípios conhecidos, uma concepção imperfeita sobre a maneira pela qual corpos são aquecidos e queimados pela ação da luz. Não é esperado mais que uma noção imperfeita dessas [p. 22] operações secretas da Natureza, pois a certeza sobre elas depende, em grande medida, de leis e princípios totalmente desconhecidos por nós.

13. Se um feixe ou raio de luz, ao passar em linha reta através de uma mesma substância pelúcida, não pode comunicar calor para suas partes internas, nem a maior quantidade de raios cruzando uns aos outros [o fará], embora agrupada no menor espaço [possível]. Disso segue que a porção de ar que se encontra no foco do espéculo mais potente não é de todo afetada pela passagem de luz através dela, não obstante continua na mesma temperatura do ar ambiente, apesar de qualquer corpo opaco, ou mesmo qualquer corpo transparente mais denso que o ar, quando colocado no mesmo lugar, ser intensamente aquecido em um instante.

14. Essa consequência, evidentemente advinda dos princípios mais claros e certos, parece não ter sido corretamente entendida por muitos filósofos, ${ }^{23}, 24$ razão pela qual [p. 23]

\footnotetext{
22 [N.T.] Embora tenha sido um argumento aparentemente engenhoso, Melvill não ofereceu nenhum fundamento para corroborá-lo.

23 [M.] Veja Boerhaave, Elementa Chemice, volume 1, sobre o fogo, corolário 5, depois, experimento 14, e corolários 1 e 7, depois experimento 17. Veja também o A System of Natural Philosophy, de Rutherford, proposição 366, sobre a parte astronômica; e as Leçons de Physique Expérimentale de Nollet, volume 4. O
} 
eu pensei ser digno de trazer alguma explicação para ela. O meio mais fácil de se satisfazer acerca disso experimentalmente é segurar um cabelo ou pelo imediatamente acima do foco de uma lente ou espéculo ou soprar uma corrente de fumaça de um cano horizontalmente acima dele. Pois, se o ar no foco for mais quente que o fluido ao redor, ele ascenderia continuamente por conta de sua rarefação e, assim, agitaria sensivelmente esses corpos leves. Ou uma lente pode ser colocada tal a ter seu foco dentro de um corpo de água ou outra substância transparente, o calor da qual pode ser examinado de tempos em tempos com um termômetro. Porém, deve-se ter atenção nesse experimento para segurar a lente o mais próxima possível do corpo transparente, a fim de que os raios, ao atingirem sua superfície mais perto que o usual, não aqueçam mais que os raios solares comuns.

15. É bem conhecido que os raios de luz, ao passarem obliquamente pela nossa atmosfera [24] são flexionados em uma curva pela quebra constante advinda do aumento contínuo de sua densidade. Mas, como toda refração sucessiva é igual a uma única refração que ocorreria ao passar de uma vez dos espaços celestes para um meio tão denso quanto a parte mais inferior de nossa atmosfera, ${ }^{25}, 26$ e [como] todas as reflexões sucessivas que podem ser feitas em cada estrato diferente são iguais àquelas que seriam feitas de uma vez a partir da superfície de um meio de mesma densidade, surge facilmente que, ao comparar as densidades do ar e da água e seus respectivos índices de refração, toda a refração e reflexão que toda a espessura de nossa atmosfera produz é muito menor que a que acontece em uma superfície de água. Consequentemente, o calor produzido em nossa atmosfera pela ação imediata da luz sobre ela deve ser também muito menor que aquela provocada na água. $\mathrm{O}$ ar parece ter grande parte de seu calor comunicado a ele a partir dos vapores opacos [p. 25] que pairam nele e da superfície geral do mar e da terra a qual ele é contíguo.

\section{Seção III}

Da aparência prateada ${ }^{27}$ de gotas de água em folhas de couve $e^{28}$

silêncio da maioria dos escritores naturais a respeito dessa verdade paradoxal mostra que eles provavelmente não estavam cientes dela.

24 [N.T.] Referência aos trabalhos de Herman Boerhaave (1688-1738), Thomas Rutherford (1712-1711) e JeanAntoine Nollet (1700-1770). Nota-se como Melvill supõe estar fazendo uma afirmação nova acerca desse tema.

25 [M.] Óptica de Newton, Livro II, parte 2, proposição 10.

26 [N.T.] Melvill basicamente copiou as descrições de Newton. Nessa proposição, o filósofo natural inglês argumentou sobre a existência de uma força dos corpos sobre a luz, produzindo a refração.

27 [N.T.] Essa é uma alusão às gotas de mercúrio líquido, que têm uma aparência prateada.

28 [N.T.] O termo utilizado por Melvill foi colewort, que não possui uma tradução exata para o português. Tratase de um termo utilizado a partir do século XIV para designar uma variedade de couve ou repolho. 
16. É comum admirar a volubilidade e o brilho de gotas de chuva que repousam sobre folhas de couve ou de alguns outros vegetais. Mas, nenhum filósofo, até onde sei, pôsse a explicar esse fenômeno curioso. Ao inspecioná-las [as gotas] minuciosamente, eu encontrei que o brilho da gota surge de uma reflexão abundante da parte plana de sua superfície contígua à planta. Eu observei, além disso, que quando a gota rola ao longo de uma parte que foi molhada, ela perde imediatamente todo seu brilho, a planta verde sendo então vista claramente através dela, enquanto que, na outra situação, é dificilmente discernida.

17. Dessas duas observações juntas, podemos concluir certamente que a gota não toca realmente a planta quando possui a aparência mercurial, mas está suspensa [p. 26] no ar a alguma distância dela, pela força de um poder repulsivo, pois não poderia haver nenhuma reflexão abundante da luz branca a partir de sua superfície inferior, a menos que houvesse um intervalo real entre ela e a superfície da planta. ${ }^{29}, 30$ (Ver Tab. iii, Fig. 2 [Fig. 2])

29 [M.] Deixe AB (Tab. iii, Fig. 4 [Fig. 3]) representar a extremidade de qualquer corpo repulsivo na água, por
exemplo um pedaço de folha de couve, CL e DM [representam] as superfícies convexas de água imediatamente
ao redor dele, e CD perpendicular a AB [representam] a tangente comum dessas curvas, a qual será a
continuação da superfície geral da água. As forças com as quais quaisquer duas partículas, E e F, são
pressionadas pela água nas direções EG, FH perpendiculares à KB, são conhecidas como KG e KH, e os poderes
repulsivos que as balanceiam devem estar na mesma proporção. Portanto, se a relação entre a ordenada e a
abcissa na curva DM puder ser de qualquer maneira encontrada por experimento, a lei do poder repulsivo poderá
ser determinada, a partir da suposição de que as partículas são influenciadas por nenhuma força a não ser pelo
poder repulsivo da linha KB e pela gravidade do fluido sobre elas. Porém, suas atrações mútuas, as quais tendem
a diminuir suas tendências laterais [de se repelir], deve ser também levada em conta, de modo a uma
determinação exata. Antes de deixar esse assunto da atração e repulsão, peço licença para propor à Sociedade [Edinburgh Philosophical Society] os movimentos espontâneos de corpos leves sobre a superfície de fluidos como algo pertinente de ser investigado. Pois, embora seja geralmente manifesto que eles dependem das diferentes formas da superfície, está longe de ser um assunto fácil explicar os casos particulares pelas leis mecânicas e hidrostáticas. O relato dos fenômenos a seguir pode ser útil para tal investigação. Caso 1. Suponha um fluido que é atraído para o lado do recipiente que o contém, e consequentemente é elevado, nos lados, a uma superfície côncava. Se um corpo que atrai o fluido for imerso e for, portanto, rodeado da mesma forma por uma elevação côncava do fluido, assim que as duas elevações começarem a se juntar, o corpo se moverá em direção ao lado do recipiente com um movimento acelerado. Caso 2. Suponha um fluido que é formado em uma superfície convexa, tanto pelo poder repulsivo do recipiente ou [pela] força coesiva de suas próprias partículas. Se um corpo leve que atrai o fluido for imerso, assim que a elevação ao redor começar a se juntar com a depressão lateral do fluido, ele começará a se mover em direção ao meio do recipiente. E, se ele for levado à força em direção à parte lateral, ele retornará de novo com um movimento acelerado.

Em ambos o primeiro e o segundo casos, se o corpo atrator for retido firmemente, e todo o fluido ficando facilmente móvel no recipiente que o contém, ele se deslocará de ou para o corpo atrator da mesma maneira como o corpo atrator fez em relação a ele. Isto é, no primeiro caso, todo o fluido se moverá tal que o corpo atrator vá para sua extremidade e, no segundo [caso], tal que ele [o corpo atrator] se afaste dela. Caso 3. Se, em um fluido que é atraído para os lados de seu recipiente, um corpo que repele o fluido for imerso, e, portanto, for rodeado por uma vala ou depressão convexa do fluido, assim que essa depressão começa a se juntar com a elevação do fluido nos lados, ela recua em direção ao meio, e se, forçadamente, [for] trazida para o lado do recipiente, fugirá a partir dele com um movimento acelerado. Caso 4. Se, em um fluido que é formado por uma superfície convexa nos lados, um corpo repelente seja imerso, assim que sua depressão começa a se unir com a depressão lateral do fluido, ele [o corpo repelente] se moverá em direção ao lado com movimento acelerado. Nesses dois últimos casos, a mesma observação em relação aos primeiro e segundo casos se aplica, ou seja, que todo o fluido se moverá com movimentos correspondentes pela força de reação, se o corpo repelente for retido 


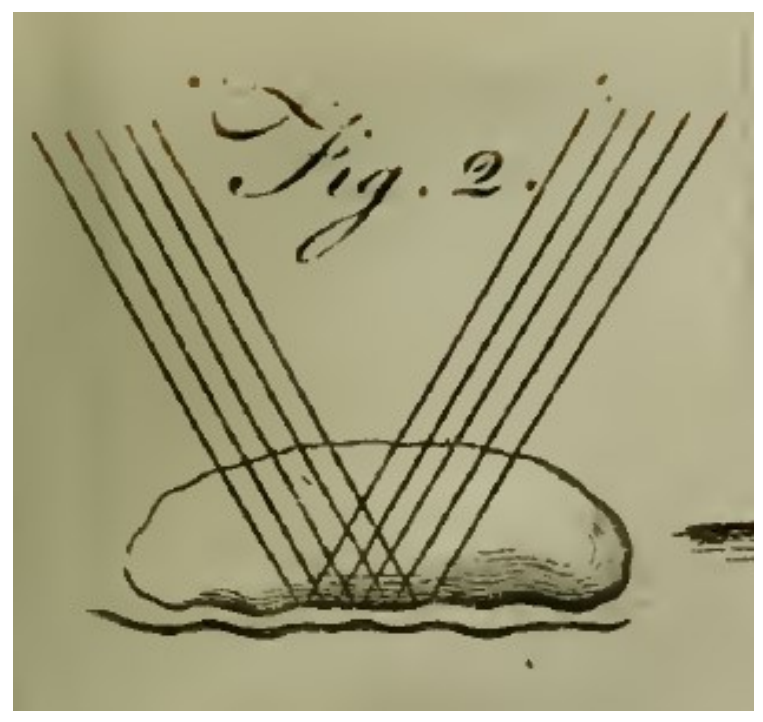

Fig. 2 - Fonte: Melvill (1756, Tab. iii).

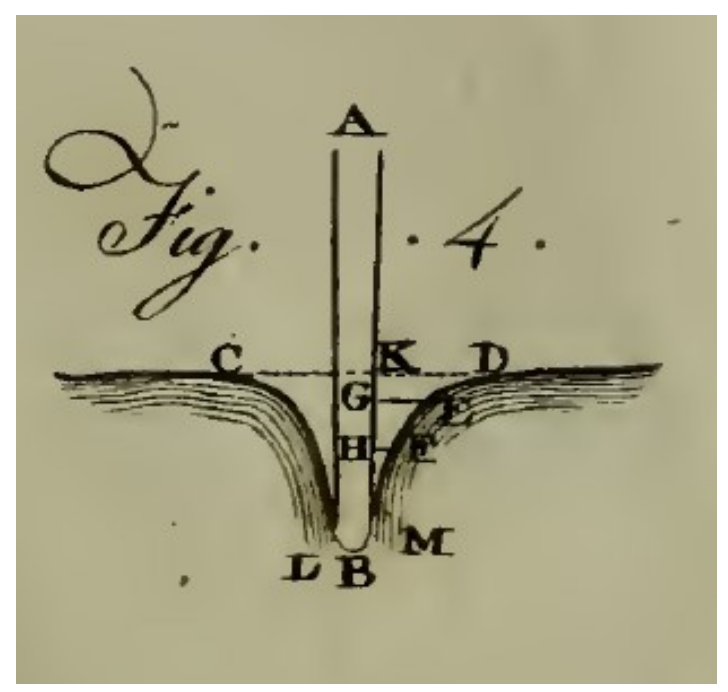

Fig. 3 - Fonte: Melvill (1756, Tab. iii).

18. [p. 27] Se aquela superfície fosse perfeitamente plana, a superfície inferior da gota também seria e, assim, mostraria por reflexão uma imagem do corpo iluminador, [p. 28] como um pedaço de prata polida. Mas, como ela é consideravelmente irregular e

firmemente. Caso 5. Se dois corpos forem imersos em um fluido, cada um deles atraindo, assim que suas elevações começam a se juntar, correrão em direção uma a outra com forças iguais e movimentos acelerados, e continuarão a se aderir.

30 [N.T.] Essa nota é particularmente interessante, pois trata-se de uma tentativa de estabelecer uma lei para a repulsão, assim como a gravitação é para a atração. Melvill, infelizmente, apenas conjectura um possível caminho para obtê-la, sem avançar a discussão. Ao longo do século XVIII, vários teóricos corpuscularistas enfrentaram dificuldades para explicar como a repulsão poderia atuar sobre a luz, causando, por exemplo, a reflexão. Para mais detalhes, ver Moura (no prelo). 
desigual, a superfície inferior torna-se irregular da mesma forma. Portanto, ao [p. 29] refletir copiosamente a luz em diferentes direções, assume a cor branca deslumbrante da prata não polida.

19. Sendo assim, está então provado por um argumento óptico que a gota não está realmente em contato com a planta que a sustenta. Concebemos facilmente de onde sua maravilhosa [p. 30] volubilidade vem e por que ela não deixa traços de umidade [por] onde ela rola.

20. Partindo de um raciocínio semelhante, podemos concluir que, quando uma agulha plana boia, ela não toca a água em nenhum lugar, mas forma ao redor dela, por conta de seu poder repulsivo, uma vala ou cama, cuja concavidade é muito mais larga que o volume da agulha. (Ver Tab. iii. Fig. 3 [Fig. 4]) Portanto, é fácil entender como a agulha nada sobre um fluido mais leve que ela mesma, visto que a quantidade de água deslocada por ela pode ser igual ao peso da agulha. Fenômenos desse tipo, em vez de serem reduzidos a princípios hidrostáticos, são comumente atribuídos à mera tenacidade da água e até mesmo usados para medir seu poder coesivo. Veja Musschenbroek, Elementa Physices ${ }^{31}$.

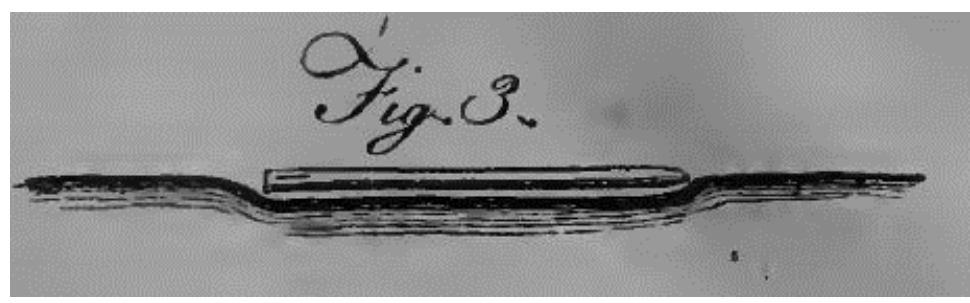

Fig. 4-Fonte: Melvill (1756, tab. iii).

21. Esse exemplo nos fornece uma justa e necessária correção à lei hidrostática usual, de que "todo corpo natatório é igual em peso a uma quantidade de fluido cujo volume é igual à parte imersa", pois, a fim de entender isso, assim como os casos comuns, ela deveria ser escrita de maneira mais geral, que "todo peso de um corpo natatório é igual ao [p. 31] peso de uma quantidade fluido deslocado por ele" 32 .

22. Esses fenômenos pareceram dignos de observação para mim aqui, tanto porque mostram a fertilidade de princípios ópticos em levar ao conhecimento de coisas inacessíveis de outro modo, quanto por exibirem uma clara prova de um poder repulsivo, similar àquele que supomos [ser] necessário pra a reflexão da luz na primeira superfície de um meio mais denso. Tampouco eu vejo como é possível considerar a suspensão da gota no ar por atrações comparativas, na qual algumas

31 [N.T.] Pieter Von Musschenbroek (1692-1761).

32 [N.T.] Em outras palavras, Melvill quer comparar pesos e não os volumes. 
outras manifestações da repulsão têm sido resolvidas, talvez, não de maneira mal sucedida ${ }^{33}, 34$.

\section{Seção IV}

Da mudança pelas quais passam os corpos coloridos em diferentes luzes ${ }^{35}$

23. Sir Isaac Newton provou abundantemente, por uma variedade de argumentos, que as cores ordinárias dos corpos naturais surgem somente [p. 32] das cores compostas daqueles raios que eles refletem; suas cores sendo determinadas pelos tipos de raios daqueles raios primitivos que eles refletem em maior quantidade. Porém, essa parte da doutrina Newtoniana receberá confirmações adicionais ao examinarmos as diferentes cores que um mesmo corpo assume quando iluminado por diferentes luzes e as quais podem ser chamadas, em distinção as primeiras, [de] suas cores extraordinárias.

24. Corpos de todas as cores principais - ou seja, vermelho, amarelo, verde e azul - são muito pouco alterados quando vistos pela luz de espíritos candentes. ${ }^{36}$ Mas, se sais forem continuamente misturados a eles durante a queima, surgem diferentes variações [de cores].

25. Quando sal amoníaco, potassa ou alumínio ${ }^{37}$ são infundidos, a cor dos corpos vermelhos aparece de alguma maneira desbotada e suja; [corpos] verdes e azuis aparecem praticamente do mesmo jeito que à luz de vela, ambos sendo vaga e dificilmente distinguíveis; [corpos] brancos e amarelos são pouco afetados como um todo.

26. Quando nitro ou sal do mar $^{38}$ são copiosamente misturados a espíritos em combustão e o todo é agitado vivamente, os mais brilhantes dos corpos vermelhos, vistos pela luz então emitida, são reduzidos a um turvo marrom fulvo, que [p. 33] em nada parecer ter de vermelho neles. Verde é transformado em outro tipo de marrom, distinguível

\footnotetext{
33 [M.] Veja Jurin sobre atração capilar, ao final das conferências hidrostáticas de Cote[s].

34 [N.T.] James Jurin (1684-1750) e Roger Cotes (1682-1716). Ambos escrevem sobre hidrostática e capilaridade. Isso sugere que o estudo das gotas estava mais associado a essas áreas que sobre forças.
}

35 [N.T.] Melvill teria sido um dos primeiros a observar a descontinuidade do espectro, mas não desenvolveu suas ideias (SUTTON, 1974, p. 43).

36 [N.T.] "Espíritos" era um termo comum nesse período, utilizado geralmente para se referir a faíscas ou a qualquer emanação decorrente de determinados fenômenos naturais.

37 [N.T.] Os termos originais utilizados por Melvill foram, respectivamente, sal ammon., potash e alum. No século XVIII, substâncias químicas não possuíam a mesma nomenclatura utilizada nos dias atuais. Sal ammon., por exemplo, provavelmente significava cloreto de amônio $\left(\mathrm{NH}_{4} \mathrm{Cl}\right)$. Já potash - em alguns textos, pot ash referia-se ao carbonato de potássio $\left(\mathrm{K}_{2} \mathrm{CO}_{3}\right)$. Por fim, alum poderia indicar vários tipos de sais de alumínio. Para mais detalhes acerca da nomenclatura vigente no século XVIII, ver Eklund (1975).

38 [N.T.] Os termos originais utilizados por Melvill foram nitre e sea-salt. Possivelmente, ele se referiu ao nitrato de potássio $\left(\mathrm{KNO}_{3}\right)$ e ao cloreto de potássio $(\mathrm{KCl})$. Novamente, assim como afirmado na nota 37, não está claro quais foram exatamente os compostos utilizados. 
somente do primeiro por uma certa inclinação a uma cor oliva pálida. Quando nitro é misturado aos espíritos, pode-se ainda ver alguns resquícios de uma cor esverdeada, a menos que esse seja despejado abundantemente. Azul escuro é dificilmente discernido do preto, exceto que ele parece o mais profundo preto dos dois. Azul claro é alterado para um marrom bem claro, de um tipo peculiar, e o amarelo sozinho aparece inalterado e extremamente luminoso. Fiz esses experimentos com diferentes tipos de corpos ricamente coloridos, tais como sedas, panos e tintas. Cobre polido, que adquiriu do ar uma cor altamente flamejante, é reduzido pela mesma luz [criada pela mistura descrita no início desse item] à aparência de bronze amarelo. As faces e mãos de espectadores parecem como aquelas de uma pessoa morta, e outras cores misturadas, que têm vermelho ou verde em suas composições, passam por mudanças semelhantes.

27. Tendo colocado um papelão com um buraco circular nele entre meu olho e a chama de espíritos, de forma a diminuir e circunscrever meu objeto, examinei a [p. 34] constituição dessas diferentes luzes com um prima (segurando o ângulo refrator para cima) e encontrei que, no primeiro caso ([item $] \mathrm{n}^{\circ} 25$ ), quando sal amoníaco, alumínio ou potassa são introduzidos nesses espíritos, todos os tipos de raios são emitidos, mas não em quantidades iguais, o amarelo sendo vastamente mais abundante que todo o resto junto, e o vermelho mais apagado que o verde e o azul.

28. Na luz de espíritos misturados com nitro ou sal do mar, eu ainda pude observar algum azul, embora excessivamente fraco e diluído. Com o último [sal do mar], o verde ficou igualmente fraco, mas com o primeiro [nitro], [ficou] muito abundante. Entretanto, quando qualquer desses sais foi usado, dificilmente eu pude ver qualquer vestígio do vermelho, pelo menos quando eles foram despejados em abundância e os espíritos constantemente agitados. A cada pequeno intervalo, contudo, os raios vermelhos se mostrariam muito manifestadamente abaixo do buraco, e os corpos vermelhos vistos por aquela luz voltavam de alguma forma às suas cores ordinárias. Foi muito divertido observar como ambos sumiam de novo de uma vez, assim que os sais e a agitação eram renovados.

A proporção na qual o amarelo brilhante excede as outras cores nessa luz [p. 35] é ainda mais extraordinária que na primeira [relatada no item 27]. Tanto que o buraco visto através do prisma aparece uniformemente desse amarelo e tão distintamente definido como [se visto] através de um vidro plano, exceto que há junto dele, no lado superior, uma faixa muito pálida de verde e azul. Corpos brancos iluminados com ela aparecem também perfeitamente definidos através do prisma. Ambos são fenômenos muito surpreendentes àqueles que estão acostumados ao uso do prisma em outras luzes heterogêneas, onde ele nunca falha em mostrar confusão nas extremidades de todos os objetos visíveis. 
29. Pelo fato de o buraco aparecer bem circular e uniforme em cor através do prisma, o amarelo brilhante que prevalece tanto sobre as outras cores deve ser de um grau determinado de refrangibilidade, e a transição dele para a cor contígua mais fraca [deve ser] não gradual, mas imediata.

30. Ao examinar filmes de bolhas de sabão na mesma luz, eu pude observar faixas luminosas separadas por escuras, o verde e o azul sendo muito fracos para afetar meu olho nessa observação. Seria um trabalho desnecessário entrar aqui em detalhes particulares sobre as razões dessas transformações diferentes de [p. 36] corpos coloridos, acima relatada ([itens] $\mathrm{n}^{\mathrm{o}} 24,25$ e 26), uma vez que, em geral, está suficientemente evidente que elas são devidas às diferentes composições das luzes com as quais elas são iluminadas. Os experimentos com primas ([itens] $n^{0} 27,28$ ) formam eles mesmos um comentário suficiente sobre o resto. ${ }^{39}$

\section{Seção V}

\section{Um comentário sobre a Nova Theoria Lucis et Colorum de Euler}

31. Euler, naquele tratado (publicado recentemente junto com alguns outros textos, sob o título de Opuscula Mathematica) pretende aperfeiçoar a hipótese de Huygeniana de vibrações ${ }^{40}$ e apoiá-la contra as objeções que fizeram Newton e seus seguidores rejeitá-la. Não devemos entrar aqui em discussão sobre essa questão, uma vez que ela requereria um argumento consideravelmente extenso e, mais precisamente, que a teoria Newtoniana da luz e cores não depende de qualquer hipótese particular com respeito à natureza íntima da luz (da mesma maneira que seu sistema de gravitação universal é independente de todas [p. 37] as hipóteses acerca da causa da gravidade). Em seu Óptica, ele estabelece integralmente suas descobertas, sequer perguntando se a luz consiste em vibrações propagadas através de um fluido ou de partículas projetadas em linhas retas a partir do corpo luminoso ${ }^{41}$. Em suas questões, onde ele aborda esse assunto $^{42,43}$, ele parece ser mais assertivo em rejeitar a hipótese de vibrações que estabelecer qualquer outra.

39 [N.T.] Nota-se, assim, que Melvill não avança na discussão do que viria a fazer parte dos estudos em espectroscopia. Não obstante, suas observações ressaltam como esse tema parecia emergir na época.

40 [N.T.] Christiaan Huygens (1629-1695). Em 1690, Huygens publicou seu Tratado sobre a Luz, contendo uma síntese de sua concepção vibracional (MARTINS, 1986). Ao contrário do que se acredita, o texto não teve grande repercussão ao longo do século XVIII (MOURA, 2016).

41 [N.T.] O próprio Newton, em cartas trocadas após a publicação da "Nova teoria sobre luz e cores" (SILVA e MARTINS, 1996), já afirmava que sua teoria de luz e cores era independente de quaisquer concepções sobre a natureza da luz (COHEN e SCHOFIELD, 1958, p. 118-119).

42 [M.] Óptica de Newton, questões 28 e 29.

43 [N.T.] Nessas questões, Newton argumentou abertamente sobre a interação entre a luz e os corpos por meios de poderes ou forças à curta distância, além de rejeitar quaisquer concepções vibracionais. 
32. No entanto, Euler também desenvolve uma nova ideia sobre a origem das cores em corpos opacos que é completamente inconsistente com a parte principal da doutrina de Sir Isaac Newton. Ele supõe que os corpos coloridos refletem a luz branca incidente do sol a partir da superfície dianteira. Não obstante, [ele também supõe] que sua aparência específica de luz, pela qual eles aparecem coloridos, é propriamente emitida pelas partes do corpo. Por exemplo, ele imagina que o vermelhão não aparece vermelho por uma reflexão mais abundante de vermelho que de outros raios incidentes, mas pela nova emissão de raios vermelhos com velocidade específica de vibração que suas partes elásticas são capazes de produzir pelo impulso da luz incidente.

33. [p. 38] É uma refutação suficiente desse sistema [o fato de] que nenhum fenômeno prova ou requer sua existência, ao passo que a teoria de Newton não apenas resolve os fenômenos, mas também é diretamente estabelecida a partir de uma variedade de experimentos. De acordo com a hipótese de Euler, um corpo de uma cor colocado em uma luz homogênea de outro, não deve aparecer da cor da luz, mas de uma [cor] intermediária entre aquela e sua cor natural, o que é contrário à experiência. ${ }^{44}$

34. Se deve ser dito: que nenhuma luz incidente é capaz de habilitar o corpo para emitir sua cor característica, mas raios de mesma cor; que o que ele denomina [de] nova luz emitida será, nesse sentido, mais propriamente luz incidente refletida.

35. O principal ou único fato que parece tê-lo levado a essa opinião é que há muitos corpos coloridos, como os metais, que são capazes de receber um fino polimento e, assim, [são capazes de] refletir regularmente a imagem de outros objetos, e ao mesmo tempo retêm suas cores características as quais são vistas em todas as posições. Aquela luz pela qual nós vemos as imagens de outros objetos neles [nos metais], [p. 39] ele admite ser a luz incidente propriamente refletida, mas a outra, ele supõe, é propriamente emitida pelas partes coloríficas do corpo. Mas, qual a necessidade em recorrer a essa suposição, quando sabemos, previamente, que as partes componentes ${ }^{45}$ de todos os corpos opacos são transparentes; que, de cada corpo transparente, há uma dupla reflexão, parte da luz incidente sendo refletida na primeira superfície e uma parte dela que passa através da primeira [e é] refletida na segunda? E quando sabemos, ainda, que corpos muito finos (como bolhas de sabão, moscovita e o ar em fendas de ar ou gelo, ou entre duas lentes) enquanto refletem alguns raios de todas as cores a partir da primeira superfície, refletem apenas cores específicas na segunda? ${ }^{46}$ Esses fatos não nos levam a supor naturalmente que o primeiro tipo de luz [no caso dos metais] seja apenas uma parte da luz incidente refletida na primeira superfície do

\footnotetext{
44 [M.] Óptica de Newton, Livro I, Parte 2, Proposição 10.

45 [M.] Óptica de Newton, Livro II, Parte 2, Proposição 2.

46 [M.] Óptica de Newton, Livro II, Parte 3, Proposição 12.
} 
corpo e o segundo uma parte do que já havia passado, refletida a partir das superfícies posteriores das partículas superficiais?

[p. 40] Seção VI

Sobre a causa da diferente refrangibilidade dos raios de luz. ${ }^{47}$

36. A fim de considerar a diferente refrangibilidade dos raios diferentemente coloridos, Sir Isaac Newton ${ }^{48}$ e vários de seus seguidores têm suposto que suas partículas são de diferentes magnitudes ou densidades. Mas, se há qualquer analogia entre a gravidade e o poder refrator, ela produzirá velocidades perpendiculares iguais em todas as partículas, quaisquer que sejam suas magnitudes ou densidades. Assim, todos os tipos de raios seriam ainda igualmente refratados.

37. Parece, por conseguinte, uma opinião mais provável - que outros têm desenvolvido que os raios diferentemente coloridos são projetados [p. 41] com diferentes velocidades do corpo luminoso: o vermelho com a maior, o violeta com a menor, e as cores intermediárias com graus intermediários de velocidade. Assim, a partir dessa hipótese, é evidente que eles serão diferentemente refratados na ordem prismática, de acordo com a observação. Uma vez que, de acordo com a doutrina de refração de Sir Isaac Newton, a velocidade de um raio, depois de entrar em qualquer novo meio está, em relação à sua velocidade inicial, assim como o seno de incidência [está] ao seno de refração, ${ }^{49}, 50$ se todas as cores se moverem com rapidez igual em qualquer outro meio, suas velocidades se tornarão necessariamente desiguais ao entrar em um meio mais denso, na proporção inversa de seus vários senos de refração. Embora supomos, então, que os raios do sol são emitidos com uma velocidade comum, [disso] seguirá que suas velocidades são desiguais no ar, vidro, água ou qualquer corpo transparente, cuja densidade de refração difere daquela da atmosfera solar ${ }^{51}$. Essa consideração é suficiente para retirar a aparência de improbabilidade de nossa hipótese.

\footnotetext{
47 [N.T.] Esse item foi publicado nas Philosophical Transactions da Royal Society. Há algumas diferenças entre o texto publicado nas Observações e aquele publicado nas Philosophical Transactions que serão indicadas oportunamente.

48 [M., nota do editor] Embora as ideias contidas nessa seção já tenham sido publicadas nas Philosophical Transactions de 1753 (vide v. xlviii, parte 1, p. 262 etc.), tendo sido comunicadas à Royal Society, pelo autor, em uma carta ao reverendo Dr. James Bradley D.D. F.R.S., ainda elas não poderiam ter sido omitidas aqui, por sua conexão com algumas das questões que seguem. Além disso, elas contêm muitas discussões que não são encontradas nas Transactions.

49 [M.] Principia de Newton, Livro I, Proposição 95.

50 [N.T.] Nessa proposição, entretanto, Newton fala da refração de corpos materiais e não da luz.

51 [M.] Veja a questão 3 abaixo.
} 
38. [p. 42] Supondo que a diferente refrangibilidade dos raios de luz procede somente de suas diferentes velocidades antes da incidência, essas velocidades devem ser, uma em relação à outra, aproximadamente como seus senos de refração [são um para o outro].

39. Sir Isaac descobriu seus senos de refração do vidro para o ar são, ${ }^{52}$ começando do violeta extremos, tais como $78,77 \frac{7}{9}, 77 \frac{2}{3}, 77 \frac{1}{2}, 77 \frac{1}{3}, 77 \frac{1}{5}, 77 \frac{1}{8}, 77$, o seno de incidência sendo 50. De onde seus senos de refração do ar para o vidro são, começando com o vermelho extremo e terminando com o violeta extremo, tais como ${ }^{53} 78000,77873$, 77797, 77663, 77496, 77330, 77220, 77000, o seno de incidência sendo 120120. Esses números, portanto, expressam aproximadamente as velocidades de vários raios no ar, antes de suas incidências ${ }^{54}$.

40. [p. 43] Disso, suas velocidades em qualquer outro meio podem ser encontradas. Pois, elas são [p. 44] para essas tais como o seno de incidência [é] para o seno de refração quando um raio passa do ar para um novo meio 55.

41. Enquanto se supõe que os raios diferentemente coloridos se movam com uma velocidade comum, quaisquer pulsos excitados no meio etéreo devem superá-los em distâncias iguais e, assim, os intervalos de reflexão e transmissão, se eles surgem dessa maneira, como Sir Isaac Newton especula, seriam todos iguais ${ }^{56}$. Entretanto, se o vermelho se move mais rapidamente, o violeta mais lentamente, e as cores

\footnotetext{
52 [M.] Óptica de Newton, Livro I, Parte 2, Proposição 3.

53 [M.] Os senos extremos são obviamente recíprocos aos primeiros, e aqueles de cores intermediárias são proporcionais à razão de 4 ao seno no experimento de Sir Isaac, 77 e 78.
}

54 [M.] As quantidades que fornecem a proporção exata das velocidades antes da incidência devem estar em uma razão constante. Os senos de refração, pelos quais os cálculos acima são feitos, têm essa condição. No entanto, é demonstrado, por outro lado, que eles oferecem apenas uma aproximação grosseira da verdade. Do que segue, talvez, uma computação mais exata pode ser feita, se um ângulo médio de incidência adequado for utilizado, embora as quantidades na regra não estão realmente em uma proporção constante.

Tab. III, Fig. 1 [Fig. 5]. Deixe dois raios, que atingem com diferentes velocidades a mesma linha de incidência $\mathrm{IC}$, sendo $\mathrm{AB}$ a superfície de um meio mais denso, serem refratados em duas linhas diferentes, CR, CV. Tomando qualquer linha $\mathrm{CD}$ na perpendicular para representar a ação total do poder refrator sobre o raio menos refrangível e CE sobre o mais refrangível; se, a partir de D e E, [linhas] paralelas a IC sejam desenhadas, encontrando os raios refratados em V, R e G, está claro que CR, CV serão tais como suas velocidades depois da refração e DR, EV tais como suas velocidades antes da incidência. Visto que toda a aceleração que um dado poder produz num corpo é, cateris paribus [mantidos inalterados os outros elementos], tal como o tempo na qual opera, $\mathrm{CD}$ deve ser para $\mathrm{CE}$ proximamente como o tempo no qual o raio mais rápido leva para passar através do espaço refrator em relação ao que o raio mais lento leva para passar pelo mesmo, inversamente, tal qual como suas velocidades antes da incidência, isto é, como EV está para DR. Porém, CD está da mesma forma para CE como DG está para EV. Portanto, DR, EV e DG são proporcionais contínuas. Dessa forma, DR está para EV na razão subduplicada de DR para DG. Mas, DR está para DG em uma razão composta de DR para DC, e DC para DG, ou seja, em uma razão composta de $\mathrm{S}$ [não indicado na figura], DCR para $\mathrm{S}$, DRC e de $\mathrm{S}$, DGC para $\mathrm{S}$, DCG. De onde DR está para EV na razão subduplicada de S, DCR x S, DGC para S, DCG x S, DRC. Ou seja, "as velocidades antes da incidência estão aproximadamente na razão subduplicada direta desses senos e a razão subduplicada recíproca dos senos dos excessos do ângulo comum de incidência sobre os vários ângulos de refração" [não há indicação da fonte para essa citação].

55 [M.] Principia de Newton, Livro II, proposição 10.

56 [N.T.] Melvill faz referência à teoria de estados de fácil transmissão e fácil reflexão, discutida no Livro II do Óptica, e mencionada em seguida. Para mais detalhes, ver Moura e Silva (2008). 
intermediárias com velocidades intermediárias, é evidente que os mesmos pulsos devem alcançar o violeta antes, as outras cores em suas ordens e, por último, o vermelho. Ou seja, os intervalos dos estados [de fácil reflexão e de fácil transmissão] devem ser menores no violeta e gradualmente maiores na ordem prismática, de acordo com a observação.

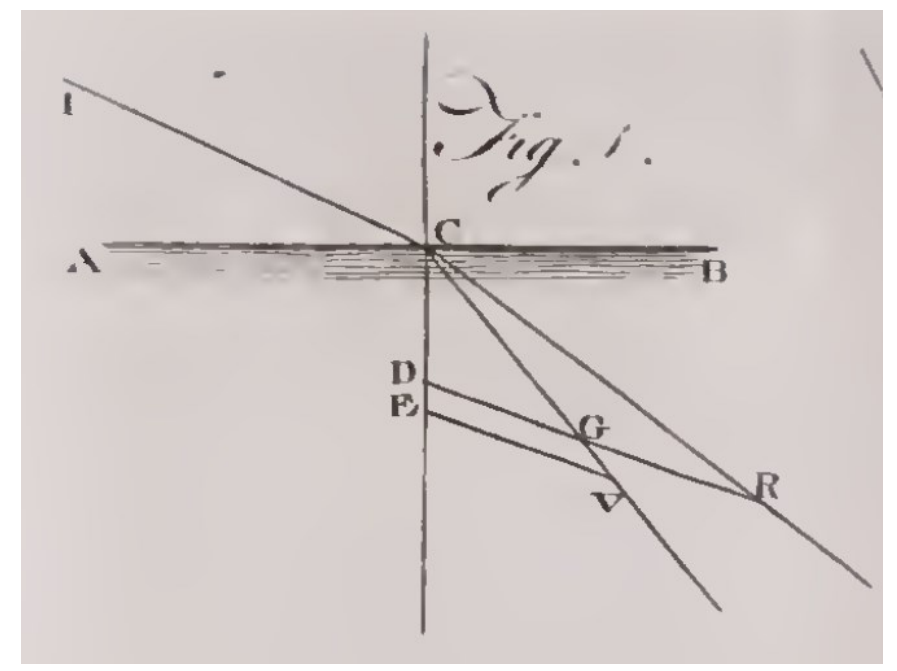

Fig. 5 - Fonte: Melvill (1756, tab. iii).

42. Como a proporção entre esses intervalos no vermelho e no violeta pode ser determinada por experimento, e a proporção de suas velocidades em qualquer meio também, pelo item $\mathrm{n}^{\circ} 40$, a velocidade dos pulsos etéreos em qualquer meio e suas distâncias de um a outro podem ser então calculadas pela seguinte regra: [p. 45] "Multiplique o produto sob as velocidades dos raios vermelhos e violetas pela diferença do intervalo de seus estados, então divide pela diferença dos dois produtos que são formados ao multiplicar o intervalo dos estados no vermelho pela velocidade do violeta, e o intervalo dos estados no violeta pela velocidade do vermelho". O quociente deve expressar a velocidade dos pulsos etéreos ${ }^{57}$.

43. ${ }^{58}$ As velocidades do vermelho e do violeta no ar são, pela estimativa acima, como $78 \mathrm{e}$ $77^{59}$, e os intervalos de seus estados são, por experimento ${ }^{60}$, como 100 e 63. Disso,

\footnotetext{
57 [M.] Deixe C denotar a velocidade dos pulsos etéreos, $\mathrm{V}$ a velocidade da luz vermelha e v aquela do violeta, I e i os intervalos de seus estados, e D a distância perpendicular de dois pulsos que se sucedem. Está claro, pela natureza da hipótese, que I está para $\mathrm{D}$ assim como $\mathrm{V}$ para $\mathrm{C}-\mathrm{V}$ e, de novo, $\mathrm{D}$ está para i assim como $\mathrm{C}-\mathrm{V}$ está para v. Portanto, ex cequo [com igual mérito] I está para i assim como $\mathrm{CV}-\mathrm{Vv}$ está para $\mathrm{Cv}-\mathrm{Vv}$, do que emerge a equação: $\frac{I-i \times V v}{I \times v-i \times V}$.

58 [N.T.] Desse ponto até a metade do item 46, há algumas diferenças entre esse texto e aquele publicado nas Philosophical Transactions, mas nenhuma significativa.

59 [M.] No meio celestial, elas são menores, [ver item] ( $\left.n^{\circ} 40\right)$, mas muito proximamente na mesma proporção.

${ }^{60}$ [M.] Veja a Óptica de Newton, Livro II, Parte I, observação 14.
} 
pelo critério agora estabelecido, a velocidade dos pulsos etéreos em relação à luz vermelha é tomada como 79763 para 78000. [p. 46] Como a luz se move do Sol para nós em 8' 12', segundo o último cálculo do Dr. Bradley, ${ }^{61}$ os pulsos de fluido etéreo serão propagados através do mesmo espaço em 8 ' 1'.

44. A distância entre os pulsos etéreos está ${ }^{62}$ para o intervalo dos estados em vermelho como a diferença entre a velocidade dos pulsos etéreos e aquela da luz vermelha está para a velocidade da luz vermelha. Esse intervalo, portanto, não é muito maior que $\frac{1}{44}$ partes do intervalo dos estados em vermelho e, assim, não excede muito $\frac{1}{2457931}$ partes de uma polegada ${ }^{63}$.

45. A velocidade dos pulsos etéreos sendo determinada, como acima, a partir dos intervalos dos estados nas duas cores extremas, como encontrado por experimento, os intervalos dos estados nos seis raios intermediários podem ser calculados a partir da teoria. Pois, o intervalo em qualquer cor deve ser, para aquele em vermelho, como um produto sob a velocidade dessa dada cor e o excesso de velocidade dos pulsos etéreos acima do vermelho estão para um produto sob a velocidade do vermelho e o excesso [p. 47] de velocidade dos pulsos etéreos acima dessa dada cor. Mas, mesmo supondo a verdade de nossa teoria, uma coincidência exata entre o cálculo e o experimento não deve ser esperada até que as velocidades dos raios sejam mais precisamente determinadas.

46. Sob a hipótese de diferentes velocidades de diferentes cores, nós podemos entender, pelo menos de maneira geral, que os intervalos dos estados podem possuir uma proporção de alguma maneira relacionada aos espaços ${ }^{64}$ ocupados pelas várias cores no espectro, uma analogia de outro modo inexplicável! ${ }^{65}$ Uma vez que, a partir das velocidades dos vários raios sob as quais dependem os intervalos dos vários estados, surgem da mesma maneira seus vários graus de refrangibilidade, os quais determinam o espaço ocupado por cada [um] no espectro ${ }^{66}$.

$\mathrm{E}$ assim podemos também conceber como os diferentes raios se habilitam a produzir diferentes sensações na mente. Pois, tendo diferentes graus de força impulsiva, eles podem causar vibrações de diferentes magnitudes ou velocidades no nervo óptico,

61 [M.] Veja The Philosophical Transactions from the year 1719 to the year 1733, abridged, and disposed under general heads de John Eames, v. VI, p. 157.

62 [M.] Veja nota *[64] na página seguinte.

63 [M.] Veja a tabela das espessuras dos filmes coloridos na Óptica de Newton, Parte 2, Livro II.

${ }^{64}$ [M.] Compare a Óptica de Newton, Livro I, Parte 2, Proposição 3 com Livro II, Parte 3, Proposição 16.

65 [N.T.] No artigo nas Philosophical Transactions, Melvill diz que isso foi descoberto por Newton e que se tratava de uma "estranha analogia" (MELVILL, 1753, p. 265).

${ }^{66}$ [N.T.] A relação entre velocidade de propagação, refrangibilidade e estados da luz proposta por Melvill foi inédita e representou sua tentativa de ir além daquilo já determinado na óptica newtoniana. 
pelas quais [p. 48], de acordo com as leis de nossa constituição, as ideias de diferentes cores podem ser excitadas ${ }^{67}$, da mesma maneira que a noção de diferentes tons vem das diferentes vibrações do ar comunicadas ao órgão auditivo. Tem sido dito que as diferentes sensações excitadas na mente não podem surgir da diferente força das partículas de luz, uma vez que a cor dos raios homogêneos não é alterada pela passagem através de meios diferentes, embora suas velocidades podem ser sempre aumentadas ou diminuídas. ${ }^{68}$ Porém, deve ser considerado que todo raio, como deve passar, afinal, através dos humores do olho de modo a [produzir] visão, atinge a retina com uma determinada velocidade, qualquer que seja o número de refrações que ele tenha passado antes. Pois, a velocidade de qualquer raio em qualquer meio estando, para sua velocidade em qualquer outro meio, em uma proporção constante, em outras palavras, o inverso dos senos de incidência e de refração, quando um raio passa de um para o outro, é manifesto que cada raio deve ter uma certa velocidade determinada em qualquer dado meio, a qual não pode ser nem aumentada nem diminuída pela passagem do raio [p. 49] previamente através de qualquer número de corpos transparentes de qualquer maneira dispostos 69 .

Assim, é impossível saber se uma alteração na rapidez com a qual um raio homogêneo atinge a retina alteraria sua cor, quero dizer, a sensação de cor produzida por ele na mente, já que é impossível alterar, a bel-prazer, a densidade daquele fluido que determina a velocidade final.

Pode-se distinguir dois efeitos diferentes do poder refrator sobre os raios de luz, a saber, a mudança de direção e a mudança de velocidade. Sir Isaac Newton provou, em relação ao primeiro, que é diferente nos raios diferentemente coloridos e de um grau determinado para cada. Ele provou, além disso, que a refração, considerada em seu primeiro efeito, não muda a cor de um raio simples. Mas, parece que, pelo que acabamos de dizer, nenhum de seus experimentos prova [p. 50] a imutabilidade dos raios simples pelos segundos efeitos da refração [a mudança de velocidade].

47. Como é de grande consequência na filosofia distinguir entre fatos e hipóteses, por mais que plausíveis, deve ser observados que as várias refrangibilidades, reflexibilidades e inflexibilidades das várias cores e suas disposições alternadas em intervalos iguais para serem refletidas e transmitidas, o que forma toda base do sistema Newtoniano, devem ser consideradas como fatos seguros deduzidos a partir de experimentos. No entanto, se as velocidades dos diferentes raios são exatamente iguais ou diferentes na maneira dita nesse instante, é nada mais que uma provável conjectura.

\footnotetext{
67 [M.] Óptica de Newton, Questão 13.

68 [M.] Veja Elementa Physices de Musschenbroek.

69 [M.] Aqui é importante observar que a hipótese que supõe os intervalos dos estados sendo determinados pela velocidade do raio concorda bem com a notável observação de Sir Isaac Newton (Óptica, Livro II, Parte 1, Observação 21) que esses intervalos em qualquer meio, em um dado ângulo de incidência, são de uma determinada magnitude, sem relação com a densidade do meio ao redor.
} 
Embora esse ponto deve ser decidido por um método proposto no futuro, ainda continuaria incerto se os estados de reflexão e transmissão são ocasionados por uma aceleração e retardamento alternados do movimento da luz, ou em alguma outra maneira $^{70,71}$.

[p. 51] E, por fim, não é mais que uma provável conjectura que tal aceleração e retardamento alternados são produzidos pela influência de pulsos excitados do meio etéreo. Mais ainda, há algumas circunstâncias nesses fenômenos que parecem dificilmente compreensíveis por uma hipótese somente, tal como, por que os intervalos dos estados são menores ${ }^{72}$ em meios mais densos e por que eles aumentam tão rapidamente e em tão intricada proporção de acordo com a obliquidade ${ }^{73}$ de incidência.

48. De acordo com a linda teoria de aberração da luz do Dr. Bradley, as estrelas parecem ser removidas de seus lugares reais a uma determinada distância pela proporção que a velocidade da Terra tem com a velocidade da luz. Está claro, portanto, que, pela nossa hipótese, uma estrela deve ter um lugar aparente diferente para cada cor diferente, ou seja, seu disco aparente deve se estender pela aberração em uma forma longitudinal que lembra o espectro prismático, tendo [p. 52] sua extremidade vermelha perto do seu lugar verdadeiro. Nas estrelas situadas perto do polo da eclíptica, seu comprimento deve continuar sempre o mesmo, embora direcionado por todas as diferentes [estrelas] secundárias da eclíptica no curso de um ano. Porém, naquelas situadas perto do ou no plano da eclíptica, [seu comprimento] deve ser maior nos limites das aberrações orientais e ocidentais, [com] a estrela recuperando sua cor e sua forma quando os lugares reais e médios coincidem. Mas, não há esperança em descobrir se nossa hipótese é verdadeira ou falsa pela consequência disso, pois o maior comprimento do disco dilatado sendo, para toda a aberração, como a diferença da velocidade do vermelho e violeta para a velocidade média da luz, isto é, como 1 para 77 aproximadamente [ver item] ( $\mathrm{n}^{\text {o } 39}$ ), não pode exceder um quarto de parte de um segundo, pois a maior aberração não é mais que cerca de vinte segundos.

49. O tempo que o violeta extremo deve tomar para se mover através de qualquer espaço deve ser, em relação àquele que o vermelho toma, como 78 para 77 . Se Júpiter for

\footnotetext{
70 [M.] Por exemplo, pode ser suposto que toda partícula de luz tem dois polos contrários, como uma magnetita, um que é atraído pelas partes dos corpos e outro repelido, e que, além de seu movimento retilíneo uniforme, as partículas dos raios diferentemente coloridos giram em diferentes períodos ao redor de seus centros. Assim, seus polos favoráveis e não favoráveis sendo alternadamente girados em direção às superfícies dos corpos, elas [partículas de luz] podem ser alternadamente dispostas à reflexão e à transmissão, e isso em diferentes intervalos, em proporção aos seus períodos de rotação.

71 [N.T.] A analogia construída por Melvill encontra semelhança com os argumentos de Newton sobre os lados da luz, conceito elaborado para explicar a dupla refração da luz (MOURA, 2014).

72 [M.] Óptica de Newton, Livro II, Parte 3, Proposição 17.

73 [M.] Ibidem, Proposição 15.
} 
suposto estar em um aspecto quadrático com o Sol, em tal caso em que os eclipses de seus satélites são mais comodamente observados, sua distância da Terra sendo aproximadamente igual [p. 53] à sua distância do Sol, a luz leva cerca de quarenta e um minutos de tempo ao passar dele para a Terra. Portanto, a última luz violeta que um satélite reflete, antes de sua total imersão na sombra de Júpiter, deve continuar a afetar o olho por uma $77^{\mathrm{a}}$ parte de $41^{\prime}$, ou 32 ', depois que o vermelho refletido ao mesmo tempo se for. Isto é, um satélite, visto da Terra, deve mudar sua cor em aproximadamente meio minuto antes de sua total imersão, do branco para uma cor esverdeada vívida, então para o azul e, por último, desaparecendo em violeta. Eu nem precisaria observar que o mesmo fenômeno deve ocorrer no momento de aparecimento, por uma sucessão contrária de cores, começando com o vermelho e terminando em branco.

50. Se esse fenômeno for realmente percebido por astrônomos, devemos ter uma prova direta suficiente das diferentes velocidades dos raios coloridos, pois eu não vejo outra causa em que esse fenômeno poderia ser racionalmente descrito. Se não for, nós poderemos concluir que os raios de todas as cores são emitidos e refletidos com uma velocidade única ${ }^{74}$.

\section{[p. 54] Seção VII}

Sobre a imperfeição de nosso conhecimento acerca das inflexões [difrações] da luz

51. Sir Isaac Newton tomou um tempo considerável ao examinar as inflexões da luz, assim como suas reflexões e refrações, mas não levou sua investigação sobre esse assunto a uma conclusão. Ele nos diz uma vez que pretendia ter feito mais experimentos, se outros assuntos não tivessem chamado sua atenção, não para confirmar opiniões pré-concebidas a si mesmo, como muitos fazem, mas para descobrir a verdadeira maneira na qual a luz é inflectida, a fim de produzir as franjas coloridas com linhas pretas entre elas. Ele complementa, contudo, com algumas questões que contêm dicas do que ele obteve sobre esse assunto a partir de suas próprias observações, a saber, que os raios de luz diferem de acordo com suas cores em seus graus de flexibilidade e que são desviados várias vezes para trás e para frente com um movimento de serpentina. Ele colocou esses pensamentos "para suscitar em outros uma pesquisa futura"75. [p. 55] Mas, até o momento, essas intenções desapontaram, [já] que poucos escritores parecem ter compreendido claramente as

74 [N.T.] A sugestão de Melvill foi encaminhada ao astrônomo James Short (1710-1768), que nada encontrou. Ver Melvill (1753, p. 268-270).

75 [M.] Óptica de Newton, p. 313 [(NEWTON, 1996, p. 250)]. Veja as duas ou três primeiras questões. 
dicas que ele deixou acerca da maneira de [como ocorrem as] inflexões, ${ }^{76}$ e ninguém, até onde eu sei [p. 56] avançou um passo além dele. É surpreendente que, antes de Sir Isaac Newton, o mundo continuou por tanto tempo inteiramente ignorante da verdadeira teoria de luz e cores, e não é por menos que, desde que ele deixou o assunto, nenhuma outra descoberta foi feita entre todas as sociedades filosóficas da Europa.

51. [p. 57] Muitos homens ilustres têm aplicado infinitos pensamentos e trabalhos sobre os mais complexos e incríveis fenômenos da Natureza, sem chegar a quaisquer descobertas exatas ou definidas, tais como terremotos, trovão e outros meteoros, magnetismo, eletricidade, vegetação, fermentação e outras operações químicas. A sutileza desses assuntos provavelmente continuará a frustrar a busca das últimas gerações. Mas, nos assuntos mais simples, mais permanentes e mais regulares, tais como luz e cores, que são capazes de medição e raciocínio matemático acurados, um observador sagaz e diligente dificilmente falhará em fazer alguns progressos, especialmente em um campo de investigação que já foi desenvolvido extensamente. Descobertas desse tipo são capazes de um tipo particular de prova que é muito bonito e convincente, a partir da coincidência exata dos efeitos computados [p. 58] com os

\footnotetext{
76 [M.] Quando qualquer corpo opaco é segurado a uma distância de três ou quatro polegadas do olho, tal que uma parte de algum objeto luminoso mais distante, como a janela ou a chama de uma vela, possa ver visto por raios passando perto de sua borda; se algum outro corpo opaco, perto do olho, for atravessado pelo lado oposto, a borda do primeiro corpo parecerá dilatar para fora e encontrar o último [o outro corpo opaco] e, ao fazê-lo, interceptará uma porção do objeto luminoso que era visto antes.

Esse fenômeno tem sido irresponsavelmente atribuído à inflexão da luz, por tal não sendo entendido nem a natureza completa da inflexão, nem [sendo] observado precisamente as circunstâncias do fato.

Deixe AB representar o objeto luminoso (Tab. iii, Fig. 5 [Fig. 6]) para o qual a visão é direcionada, CD o objeto opaco mais distante, GH o mais próximo e EF o diâmetro da pupila. Junte ED, FD, EG, FG e os prolongue até encontrar $\mathrm{AB}$ em K, N, M e L. É evidente que as partes AN, MB do objeto luminoso não podem ser vistas. Mas, tomando qualquer ponto a entre $\mathrm{N}$ e $\mathrm{K}$, e desenhando aDd, uma vez que a porção $\mathrm{dF}$ da pupila é preenchida com luz fluindo daquele ponto, elas devem ser visíveis. Qualquer ponto $b$ entre a e $\mathrm{K}$ deve preencher $\mathrm{fF}$ de uma porção maior da pupila e, portanto, deve aparecer visível. Da mesma forma, qualquer ponto c entre $\mathrm{b}$ e $\mathrm{K}$ deve aparecer mais brilhante que $\mathrm{b}$, porque preenche uma grande porção $\mathrm{gF}$ com luz. O próprio ponto $\mathrm{K}$ e qualquer outro ponto no espaço KL deve aparecer completamente brilhante, uma vez que eles mandam feixes inteiros de raios EKF, ELF para o olho. O brilho visível de cada ponto de L para $\mathrm{M}$ deve decrescer gradualmente, assim como de $\mathrm{K}$ para $\mathrm{N}$, isto é, os espaços $\mathrm{KN}$, LM aparecerão como bordas turvas ensombradas ou franjas adjacentes aos limites dos corpos opacos. Quando o canto G é trazido para tocar a linha reta KF, sua penumbra se une e, assim que ela chega a NDF, o fenômeno acima começa. Pois, ele não pode passar aquela linha reta sem encontrar alguma linha aDd desenhada de um ponto entre $\mathrm{N}$ e $\mathrm{K}$ e, ao interceptar todos seus raios que atingem a pupila, torná-lo visível. Ao avançar gradualmente à linha $\mathrm{KDE}$, ele encontrará outras linhas bDf, cDg etc. e, portanto, tornar sucessivamente invisíveis os pontos b, $\mathrm{c}$ etc. de $\mathrm{N}$ a K. Assim, o limite do corpo opaco fixo CD deve parecer dilatar para fora e cobrir todo o espaço NK, enquanto GH, pelo seu movimento, cobre MK. Quando GH é colocado a uma distância maior do olho, CD continuando fixo, o espaço OP a ser ultrapassado para interceptar NK é menor e, logo, com um movimento igual de GH, a dilatação aparente de CD deve ser mais rápida, o que é visto como verdadeiro pela experiência. Se ML representa um objeto luminoso e REFQ [R não está visível na Fig. 6] qualquer plano exposto à sua luz, o espaço FQ deve ser inteiramente escurecido dos raios e o espaço FE será ocupado por uma penumbra gradualmente mais escura de E a F. Deixe agora GH continuar fixo e CD se mover paralelamente ao plano EF e, assim que passa a linha LF, é evidente que a sombra QF parecerá se dilatar para fora. Quando CD chega a ME, tal que cubra com sua sombra o espaço RF, QF por sua extensão cobrirá FE. Isso é visto também como verdadeiro por experimento.
} 
verdadeiros, em relação à quantidade. Muitos exemplos disso ocorrem nos escritos de Sir Isaac Newton e em toda sua filosofia matemática, tal como o cálculo das irregularidades da lua, das marés, da precessão dos equinócios, da resistência de fluidos e, na óptica, de seus cálculos das dimensões do arco-íris, da aberração das cores, dos intervalos dos estados [de fácil] reflexão e transmissão e dos anéis coloridos refletidos por espéculos transparentes espessos.

O que eu tenho de mais a oferecer em relação à luz e cores, consistindo principalmente de dúvidas, dificuldades ou vagas conjecturas, devem ser propostas sob a forma de questões.

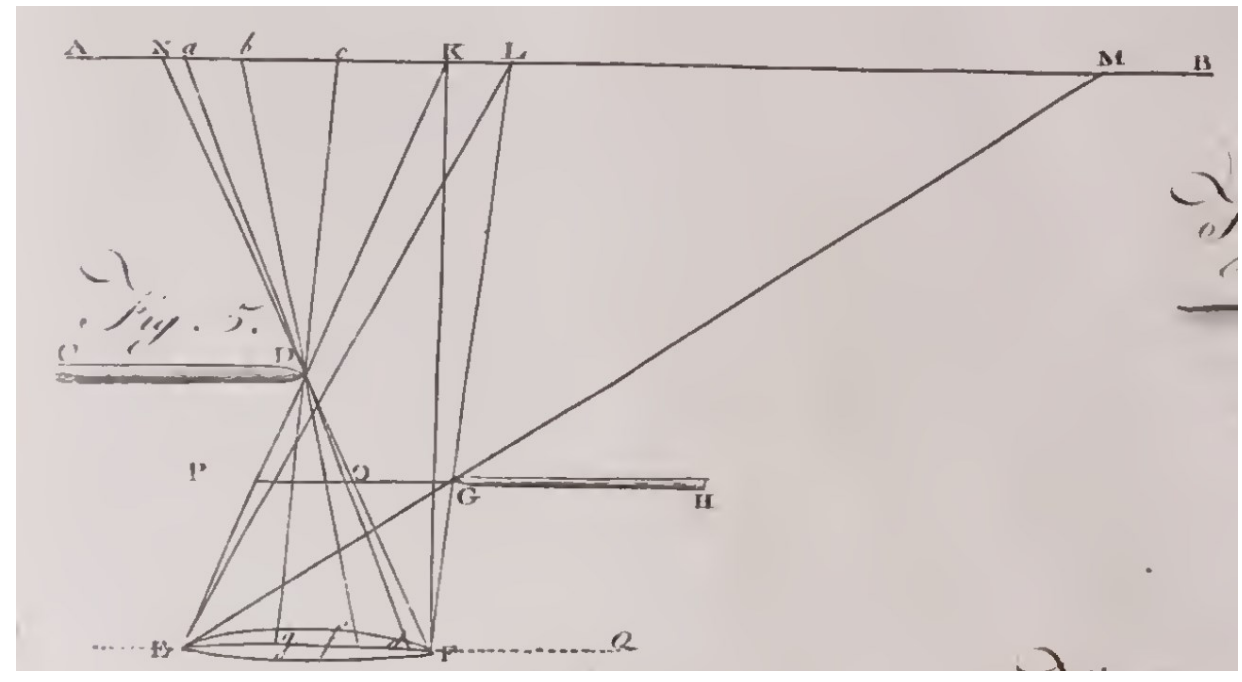

Fig. 6-Fonte: Melvill (1756, tab. iii).

\section{[p. 59] Seção VIII}

Questões, consistindo de dúvidas, dificuldades e conjecturas acerca da luz, das cores e dos corpos coloridos ${ }^{77}$.

QUESTÃO 1. Não são os raios, emitidos por todos os tipos de corpos luminosos, semelhantes àquele do Sol, tanto em cor quanto em graus de refrangibilidade? E os corpos luminosos não diferem uns dos outros apenas de acordo com as cores que eles emitem mais copiosamente, da mesma maneira que corpos opacos são distinguíveis pelas cores de luz incidente que eles refletem em grande abundância? (Veja [itens] $\mathrm{n}^{\mathrm{o}}$ 24, 25, 26, 27, 28 e 29). Mas, para tornar nossa indução suficientemente forte, não deveriam ser feitos experimentos com as luzes de uma maior variedade de corpos? E não nos conduziria ao posterior esclarecimento dessa questão formar, pelo método de

77 [N.T.] Não deixa de ser interessante o fato de Melvill finalizar seu ensaio sobre luz e cores em forma de questões, assim como Newton no Óptica. 
Sir Isaac Newton $^{78}$, um feixe de luz solar consistindo de tais cores e em tais proporções, como são vistas em luzes de sais e espíritos queimando, e então observar nelas a aparência [p. 60] de corpos coloridos? Além disso, não são os intervalos dos estados [de fácil transmissão e fácil reflexão], em raios de qualquer cor, os mesmos no mesmo meio, a partir de qualquer corpo luminoso do qual são emitidos? Pois, se esses intervalos fossem diferentes, não haveria mudanças nas cores dos corpos não atribuídas pelas composições de luz com as quais são iluminados? ${ }^{79}$

QUESTÃo 2. Todos os corpos, dos mais fracos aos mais brilhantes, não emitem suas luzes de qualquer cor específica com uma velocidade determinada, uma vez que é encontrado por experimento que eles são todos igualmente refratados pelo mesmo meio? E, portanto, o diferente esplendor dos corpos luminosos não procede totalmente da diferente densidade de suas luzes em distâncias iguais? E isso não é confirmado pela igualdade da aberração da luz de Bradley em estrelas fixas de todas as magnitudes? ${ }^{80}$ Se for assim, a força comparativa de diferentes luzes, tais como as do sol, da lua, de uma velha etc. podem ser facilmente estimadas ao encontrarmos as maiores distâncias nas quais o mesmo corpo opaco é visível quando iluminado por cada uma delas, ou os limites [p. 61] além dos quais é invisível ao olho, pois as densidades das luzes incidentes estão muito proximamente como os quadrados das distâncias desses limites do objeto ${ }^{81}$. Toda a luz não se move com a mesma velocidade depois da reflexão como antes, já que o ângulo de reflexão é sempre igual ao ângulo de incidência? A exceção da luz elétrica, feita por alguns, é vista como não menos que um erro que como misturar o corpo luminoso com sua luz ${ }^{82}$. Mas, a melhor prova dessa proposição vem da coincidência dos cálculos da velocidade da luz, da equação dos eclipses de Júpiter e da aberração das estrelas fixas ${ }^{83}$.

78 [M.] Óptica de Newton, Livro I, Parte 2, Proposição 11.

79 [N.T.] Na primeira edição, havia aqui uma nota de rodapé apenas com a palavra "Art”, indicando que Melvill se referiria a algum outro item de seu texto. Na segunda edição, essa nota foi removida.

80 [M.] The Philosophical Transactions from the year 1719 to the year 1733, abridged, and disposed under general heads de John Eames, v. VI, p. 158.

81 [M.] Deixe A e a (tab. iii, Fig. 6 [Fig. 7]) denotar o mesmo ou dois corpos iguais de mesma cor iluminados com diferentes luzes e B, b, os limites. Como supomos que a luz recebida pelo olho, nesses pontos, é exatamente o suficiente para afetá-lo sensivelmente e não mais, as duas luzes nessas diferentes distâncias devem ser proximamente da mesma densidade. Tomando, portanto, em $\mathrm{AB}$ uma linha $\mathrm{A} ß$ igual a ab, a densidade da luz em $\beta$ deve estar para a densidade da luz em b proximamente como $\mathrm{AB}^{2}$ para $\mathrm{Ab}^{2}$. E é evidente que essas densidades, em distâncias iguais, devem ser como toda quantidade de luz refletida, e essas de novo muito proximamente como toda quantidade de luz incidente.

82 [M.] Elementa Physices de Musschenbroek, última edição, em seu capítulo sobre eletricidade.

83 [M.] The Philosophical Transactions from the year 1719 to the year 1733, abridged, and disposed under general heads de John Eames, v. VI etc. 


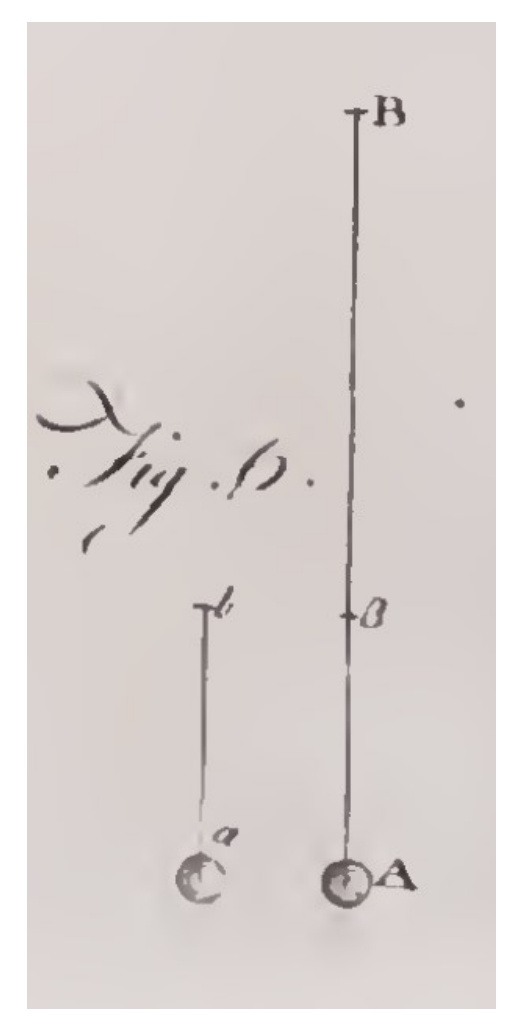

Fig. 7 - Fonte: Melvill (1756, tab. iii).

[p. 62] QUeSTÃo 3. A luz é emitida com a mesma velocidade em qualquer meio em que o corpo luminoso seja colocado? Ou, pelo contrário, ela não é emitida com maior velocidade em meios mais densos e isso em proporção com seus poderes refratores? $\mathrm{O}$ mesmo argumento do qual tomamos em geral a velocidade igual da luz emitida por todos os tipos de corpos luminosos parece provar a verdade dessa última proposição. Pois, uma vez que raios de qualquer cor, do sol e de uma vela, por exemplo, são igualmente refratados por uma superfície de vidro ou água, podemos concluir que suas velocidades no ar são iguais. Pelo que, se a densidade da atmosfera do sol, contígua à sua superfície, for diferente da densidade do nosso ar mais abaixo, como pode ser seguramente presumido, seus raios devem ser emitidos com mais ou menos velocidade que aqueles de uma vela. Do contrário, eles não poderiam ter a mesma velocidade depois em qualquer meio comum, pois a velocidade com a qual qualquer raio é emitido está, pelas leis da refração, para sua velocidade em qualquer dado meio, assim como o seno de refração [está] para o seno de incidência, quando um raio passa do [p. 63] meio de emissão para o dado meio.

QUESTÃo 4. Se a atmosfera não é muito aquecida pela passagem da luz do sol através dela, mas principalmente por seu contato com a superfície aquecida do globo, como mostramos acima [item ( $\left.\mathrm{n}^{\mathbf{0}} 15\right)$ ], não poderíamos então dar uma razão muito simples e plausível do porquê é mais frio em todos os climas no topo das montanhas muito altas, a saber, porque elas são removidas a maior distância da superfície geral da Terra? Pois 
é bem conhecido que um fluido aquecido por seu contado com um corpo sólido decresce em calor em alguma proporção inversa à distância do corpo. Mas, para ter essa questão totalmente respondida, a temperatura do ar no vale e no topo da montanha deve ser observada cada hora ambos dia e noite, e cuidadosamente comparadas.

QUESTÃo 5. Do que foi posto na Seção 2, acerca do modo como age a luz em aquecer os corpos, não é razoável supor que o calor produzido por um dado número de raios em um corpo opaco de dada magnitude deve ser maior [p. 64] quando os raios estão mais inclinados um ao outro que quando eles estão menos inclinados? Pois, a direção das vibrações criadas pela ação da luz, seja nas partículas coloríficas ou naquelas de ordem inferior, interferirão mais uma com a outra, do que os choques e colisões interiores deverão aumentar. Além disso, as partículas coloríficas dos corpos opacos, sendo dispostas em várias situações, talvez, sobre o todo, os raios cairão mais diretamente em cada [uma das partículas], quanto mais eles estão inclinados um ao outro. Essa não é a razão que tem sido destacada por filósofos ${ }^{84,85}$ de que o calor da luz sol coletada em um cone aumenta ao aproximarmos o foco em uma proporção muito mais que de acordo com sua densidade? Que é pequena a diferença de ângulo no qual os raios atingem qualquer partícula de uma dada magnitude colocada em diferentes distâncias do foco não é prova de que o fenômeno não pode ser atribuído a isso, uma vez que não sabemos em qual grande proporção uma ou ambas as circunstâncias agora mencionadas podem operar. Contudo [p. 65], que isso procede não de qualquer ação dos raios sobre um outro, como têm sido insinuado ${ }^{86}$, é evidente disso, que cada raio particular, depois de passar através do foco, preserva sua própria cor e sua própria direção, da mesma maneira como se estivesse sozinho.

QUESTÃo 6. Não pode ser inferido que as partes componentes dos corpos opacos são maiores que aquelas dos [corpos] transparentes, como a teoria requer ${ }^{87}$, pela simples observação de que os primeiros, tais como metais, pedras, madeiras etc., quando quebrados transversalmente, mostram uma aspereza e desigualdade na fratura, enquanto que os últimos, tais como vidros, cristais, gemas, gelo etc. parecem tão lisos, quase como quando foram polidos?

QUESTÃO 7. Os experimentos de Newton com o cristal-da-Islândia e o cristal de rocha ${ }^{88}$ não provam suficientemente que os raios de luz têm propriedades permanentes diferentes em seus diferentes lados, em relação a esses dois corpos? Não devemos,

\footnotetext{
84 [M.] Elementa Chemice de Boerhaave.

85 [M.] Elementa Physices de Musschenbroek, § 1040.

86 [M.] Elementa Physices de Musschenbroek, § 1040.

87 [M.] Óptica de Newton, Livro II, Parte 3, Proposição 4.

88 [N.T.] Veja nota 71.
} 
portanto, conceber cada partícula de luz como mantendo sua posição invariavelmente enquanto se move para frente, pelo menos não a ponto de girar em torno [p. 66] de seu centro perpendicularmente à direção de seu movimento? Não seria adequado testar como a luz é inflectida ao passar muito próxima pelos vários ângulos e lados desses fósseis?

QUESTÃo 8. Não seria possível provar por experimento o que Sir Isaac Newton considerou garantido como uma suposição razoável, de que filmes transparentes finos, de qualquer cor uniforme, divididos em fragmentos menos, comporiam um pó de igual coloração ${ }^{89} \mathrm{E}$ isso não tenderia a fortalecer a analogia entre as cores de tais filmes com aquelas de corpos naturais? Para esse propósito, eu tentei congelar bolhas de sabão, mas nunca pude fazê-las durar até que elas pudessem congelar, exceto quando eram muito grossas para mostrar cores. Entretanto, não duvido que com o devido cuidado, tal coisa possa ser feita, especialmente se a água ensaboada, em vez de ser soprada em bolhas com um tubo, for feita como uma superfície plana em qualquer moldura de madeira ou de metal. Pois, os lados de uma superfície plana possuindo uma proporção maior à sua área que a base de um segmento esférico à sua superfície, o congelamento seria rapidamente [p. 67] comunicado a toda água no primeiro caso que no último. Há também essa vantagem de usar uma superfície plana de bolha de sabão, que, antes de congelar, o observador pode alongar qualquer cor particular ou série de cores que ele escolher a uma maior extensão, ao afaga-la com um dedo molhado. Por essa razão, dentre outras, considerei uma maneira mais conveniente de examinar as várias ordens de cores, que [utilizando] bolhas esféricas aderidas a um plano. Talvez resina derretida possa ser jogada em um filme fino antes que endureça, pois eu tenho frequentemente utilizado feito bolhas com um cachimbo até elas ficarem coloridas. Eu não conheço outros meios nos quais as várias ordens de cores possam ser preservadas para uma inspeção deliberada, a não ser em um plano congelado de água ou de resina, ou na escória permanente que aparece em metais aquecidos. Eu contei, no lado de uma chaleira de cobre bem polida, as primeiras seis ordens de cores distinta e regularmente ordenadas na mesma sucessão na qual elas aparecem em bolhas de sabão; a primeira ordem sendo formada naquela parte da chaleira que foi menos aquecida.

[p. 68] Questão 9. O que é a inflexão da luz em direção às tênues bordas dos corpos senão um caso particular de refração, no qual os raios, depois de serem desviados pelo por atrativo [dos corpos], são levados para além da superfície refratora, perdendo a chance de entrar, por conta de sua pequena extensão? Pois, se a superfície da borda for prolongada, ela se encontrará com os raios inflectidos e, assim, a inflexão se tornará propriamente uma refração. E, da mesma maneira, podemos considerar a inflexão da luz para fora da borda dos corpos como uma espécie de reflexão.

89 [M.] Óptica de Newton, Livro II, Parte 3, Proposição 5. 
QUESTÃo 10. Não é impossível que um animal possa enxergar, se o diâmetro de seu olho for muito menos que o intervalo entre os estados de transmissão e reflexão na água, a saber, que $1 / 375000$ partes de uma polegada?

QUESTÃo 11. Há muitos experimentos que mostram que um raio amarelo e um azul misturados formam um verde; um pó amarelo e um azul [formam] um pó verde; e uma mistura de raios ou tintas de todas as cores prismáticas [formam] um raio ou tinta branca. Agora, os mesmos experimentos não demonstram igualmente que a noção de verde é uma confusão ou mistura das [p. 69] noções de amarelo e azul, [que] a noção de branco [é] uma mistura das noções de todas cores e [que], em geral, as noções de todas as cores compostas [são] uma mistura das noções de suas [cores] constituintes? Nos experimentos que Sir Isaac Newton realizou com o instrumento dentado, as cores componentes não são, de fato, apresentadas ao olho todas de uma vez. Do contrário, elas seguem uma à outra em uma sucessão tão rápida, que suas respectivas impressões permanecem no olho até serem renovadas e, portanto, elas devem afetar a mente de uma vez. ${ }^{90}$ Se um pedaço [p. 70] de papel for todo manchado com pequenos pontos de azul e amarelo, ele aparecerá verde para um olho localizado a uma grande distância para distinguir [p. 71] os pontos separados. De qualquer forma que a sensação for efetuada, é certo que os órgãos que recebem o primeiro impulso de objetos externos não podem nos comunicar quaisquer ideias se eles ou as impressões feitas por eles

90 [M.] É dessa maneira que os filósofos explicam (Óptica de Newton, Questão 16) o aparecimento de um círculo faiscante que é feito por um corpo em chamas rodopiado rapidamente. Daremos aqui um relato de alguns outros fenômenos que surgem do mesmo princípio.

Se uma vara branca for movida rapidamente para trás e para frente com um movimento angular, todo o espaço circular que ela percorre aparecerá branco. Porém, não igualmente, sendo mais fraco e mais diluído no meio e mais brilhante em direção aos dois lados, que parecem ser distintamente terminados com duas varas brancas cruzando com uma com a outra no centro da rotação (veja Tab. iii, Fig. 7) [Fig. 8].

A impressão total feita sobre o olho por partes iguais pequenas da área deve estar tanto quanto a quantidade de luz emitida dela e a frequência dos retornos da vareta a ela [à área], isto é, inversamente [proporcional] [em relação a] o tempo entre os retornos da vareta. Deixe $\mathrm{ABC}$ representar a área circular e $\mathrm{DC}$ a linha dividindo-a; a vareta sempre retorna à DC depois do tempo de uma vibração e a qualquer outra linha $\mathrm{EC}$ entre $\mathrm{DC}$ e $\mathrm{AC}$ ou $\mathrm{AB}$ o tempo médio de seu retorno é o mesmo, pois ela retorna alternadamente em duas vezes o tempo de descrever $\mathrm{AE}$ e duas vezes o tempo de descrever $\mathrm{EB}$, tal que dois intervalos sucessivos de seus retornos sejam iguais ao tempo de duas vibrações. Porém, os intervalos dos retornos às linhas $\mathrm{AC}$ ou $\mathrm{CB}$ são manifestadamente iguais ao tempo de duas vibrações inteiras. Portanto, o brilho da área em DC ou em qualquer linha entre DC e AB ou BC deve ser simplesmente como a quantidade de luz emitida de porções pequenas iguais da área, ou seja, na proporção inversa das velocidades da vareta quando nessas linhas. Disso fica claro que a área deve ser incomparavelmente mais brilhante em $\mathrm{AC}$ e $\mathrm{BC}$, onde ela [a vareta] para, que em qualquer outro lugar, não obstante que os intervalos de retorno do outro lado são o dobro, ou seja, ela [a área] aparecerá distintamente limitada com uma vareta branca em cada lado.

Se a vareta for agitada com rápidas e pequenas vibrações próprias, ao fixa-la contra algum corpo sólido imediatamente antes de ser agitada para frente e para trás com o movimento angular, a área aparece dividida, em intervalos iguais, por um grande número de varetas distintas, quase tão brilhantes como as duas laterais (Tab. iii, Fig. 8) [Fig. 9], parecendo raios de um leque estendido. A razão desse curioso fenômeno é claramente essa, que seu movimento angular, estando alternadamente na mesma e na direção contrária às suas vibrações particulares, é alternadamente acelerado e retardado ou parado. No espaço onde é acelerado, a área deve aparecer muito diluída e onde ele é grandemente retardado ou levado ao repouso, deve aparecer muito luminosa ou dividida por varetas brancas, pela mesma razão que elas aparecem [dessa forma] nos lados. 
forem melhores que uma certa magnitude definida. Um número de coisas separadamente intangíveis, se juntadas, pode ser sentido pelo toque. Um certo número de pontos invisíveis se torna suficiente para afetar a percepção pelos seus raios unidos, e um certo número de sons muito pequenos para serem ouvidos separadamente, por fim, formam um som audível ${ }^{91}$.

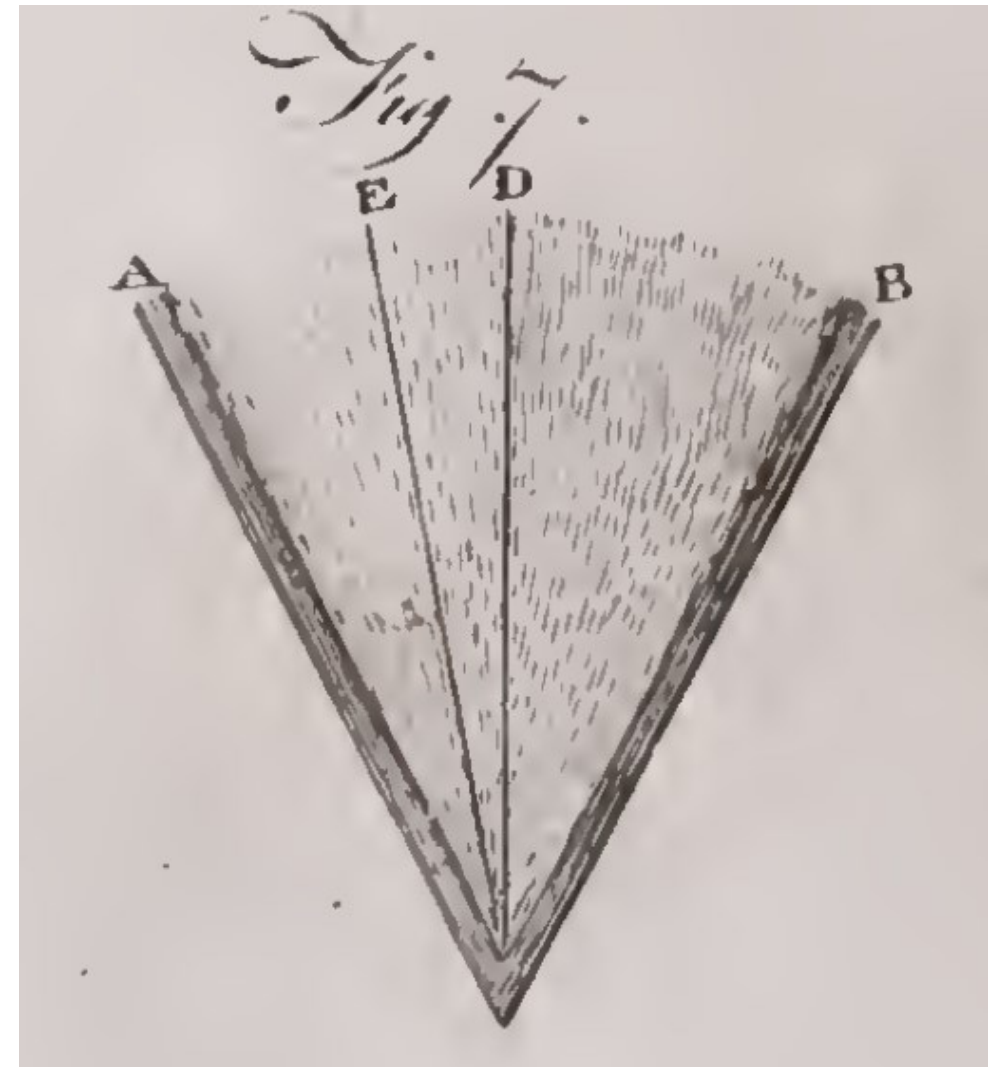

Fig. 8 - Fonte: Melvill (1756, tab. iii).

91 [M.] Alguns céticos têm argumentado contra a divisibilidade infinita da quantidade, uma vez que a imaginação logo chega em seu mínimo, alegando disso que nossa ideia de extensão envolve a noção de indivisíveis e é como se fosse composta delas. Nada corpóreo pode ser imaginado ou concebido que não seja concebido como visto, manuseado ou de alguma outra maneira sensivelmente percebido. Ideias imaginativas são nada mais que transcrições ou imagens de sensações e, portanto, devem estar confinadas pelos mesmos limites e da mesma maneira que a sensação. Agora, o mínimo sensível é mais propriamente em todos os casos uma transição confusa, indistinta e incerta do perceptível para o não perceptível que a percepção clara de um ponto indivisível em magnitude, pois sua magnitude depende do brilho do objeto. Que nada possa ser concebido ou imaginado que é menor que um certo volume, é nada mais que um argumento contra a divisibilidade infinita da quantidade que aquele de que nada pode ser sentido ou visto [sendo] menor que aquele tamanho, o que, evidentemente, de cada lupa e de cada distância diferente de um objeto, não depende da constituição da coisa percebida, mas daquele do observador ou dos meios e circunstâncias de sua percepção.

Tampouco seguiria, embora fosse garantido que o mínimo visível é distintamente visto como um ponto indivisível, que a noção de extensão, recebida pela visão, fosse feita de noções de indivisíveis, pois recebemos a ideia de extensão por aquele movimento do olho que é necessário para direcionar seu eixo a diferentes objetos ou partes de um objeto. É sabido que a geração de quantidade pelo movimento é preferida pelos melhores escritores, por essa mesma razão, que necessariamente exclui a noção de indivisíveis. Deve ser também lembrado que um objeto visível não é dividido pelo olho em um número contíguo de mínimos visíveis, pois para qualquer ponto matemático no objeto [que] o olho é direcionado, um mínimo visível pode ser visto lá por meio de uma certa porção do objeto que imediatamente o rodeia. 


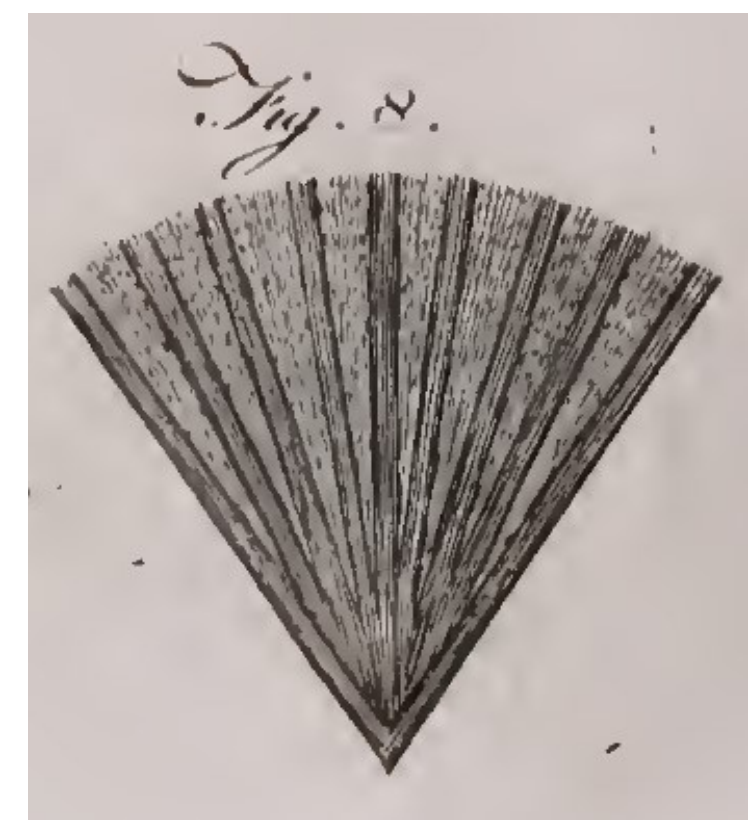

Fig. 9 -Fonte: Melvill (1756, tab. iii).

[p. 72] QUESTÃo 12. Uma vez que os corpos obtêm suas cores de qualidades originais e imutáveis daqueles raios que eles refletem mais copiosamente, eles não deveriam aparecer da mesma cor, não importa se vistos a distâncias maiores ou menores? É por isso, portanto, que os planetas cujas partes sólidas são cobertas provavelmente por vegetais, e devem, assim, refletir uma grande quantidade de [p. 73] raios verdes, aparecem quase inteiramente brancos quando vistos da Terra? Isso não deve ser considerado da mesma maneira que a mudança de cor observável em objetos terrestres vistos através de uma grande região da atmosfera? Uma montanha coberta com o verdor mais fresco, a uma distância de doze ou quinze milhas, parece azulada, e a vinte ou trinta [milhas] especialmente se o ar for engrossado, se degenera em um objeto turvo branco, tal que alguém dificilmente pode distingui-la das nuvens que margeiam o horizonte. Em relação aos planetas primários, pode também ser respondido, que talvez nós os vejamos principalmente pela luz refletida do ar e dos vapores que os rodeiam.

QUESTÃo 13. Por que é tão difícil distinguir corpos verdes de azuis pela luz de uma vela?

QueSTÃo 14. Disso procede a cor azul do céu? Uma vez que é certo que nenhum corpo assume qualquer cor particular, mas [as tem] porque ele reflete um tipo de raios mais abundantemente que o resto, e uma vez que não deve ser suposto que as partes constituintes do ar puro são grossas o suficiente para separar quaisquer cores delas mesmas, não devemos concluir [p. 74] com Sir Isaac Newton ${ }^{92}$ que os raios que fazem o violeta e o azul são refletidos mais abundantemente que o resto pelos mais finos

92 [M.] Óptica, Livro II, Parte 3, Proposição 7. 
vapores difundidos através da atmosfera cujas partes não são grandes o bastante para dar a eles a aparência de nuvens opacas visíveis? Aqueles que dizem ${ }^{93}$ que o azul etéreo se origina de uma mistura da luz branca do sol refletida fracamente pela atmosfera com a escuridão perfeita do espaço celestial atrás, não revivem a antiga confusa ideia de que todas as cores podem ser formadas por certas composições de luz e sombra? Embora a atmosfera reflita mais raios azuis que o que surge da formação do branco perfeito, é fácil conceber como corpos coloridos, iluminados por ela, podem não ser sensivelmente impregnados de azul. Vamos supor que a atmosfera reflita $1 / 4$ mais de raios azuis que de outras cores e que o vermelhão reflete 19/20 dos raios vermelhos que incidem sobre ele, e 1/20 de cada outra cor. Então, está claro que os raios vermelhos refletidos pelo vermelhão ainda excederão o azul refletido por ele, assim como 19 excede $1+1 / 4$, [p. 75] tal que a pureza de sua cor vermelha não será sensivelmente prejudicada. Mas, para mostrar que, em circunstâncias apropriadas, a cor azulada do céu da manhã pode ser vista em corpos iluminados por ela, como é frequentemente contestado ${ }^{94}$, exponha aos raios solares, em um dia claro e sem nuvens, uma folha de papel branco, e coloque sobre ela qualquer corpo opaco. Você perceberá que o espaço da sombra que é iluminado somente pelo céu parece notadamente azulado, comparado com o resto do papel que recebe diretamente a luz sol. Se certas tintas brancas e pretas misturadas produzem azul, é porque o preto não é perfeitamente sombra, mas azul escuro ou roxo ${ }^{95,96}$. Qualquer mistura de branco e o verdadeiro preto pode somente formar um branco ou cinza fracos, que não tem mais afinidade com azul que com vermelho ou qualquer outra cor.

QUESTÃo 15. A opinião que Sir Isaac Newton parece ter tido ${ }^{97} \mathrm{e}$, desde ele, a maior parte dos filósofos, acerca da causa das várias cores [p. 76] refletidas pelas nuvens no nascer e no pôr-do-sol, não está sujeita a grandes dificuldades? Pois, por que as partículas das nuvens deveriam se tornar de tal magnitude para separar essas cores em um momento particular e nunca em qualquer outro? E por que elas são raramente, se são, vistas pintadas de azul e verde, como de vermelho, laranja e amarelo? Não seria mais crível que a separação dos raios seja feita ao passar através da atmosfera horizontal? E que as nuvens somente refletem e transmitem a luz do sol, assim como qualquer corpo meio transparente sem cores faria em seu lugar? Pois, uma vez que a atmosfera, como dito na última questão, reflete uma maior quantidade de raios azuis e violetas que do restante, a luz do sol transmitida por ela deve tender para o amarelo,

\footnotetext{
93 [M.] Spetacle de la Nature: Or, Nature Display'd, v. IV e Elementa Physices de Musschenbroek, § 1403.

94 [M.] Elementa Physices de Musschenbroek, § 1403.

95 [M.] Ibid., § 1172

96 [M.] Óptica de Newton, Livro II, Parte 3, Proposição 7.

97 [M.] Óptica de Newton, Livro II, Parte 5, Proposição 5, perto do fim.
} 
laranja ou vermelho, especialmente ao passar por um grande extrato de ar. Consequentemente, todos devem ter notado que a luz horizontal do sol é algumas vezes tão densamente pintada que objetos iluminados diretamente por ele aparecem em um forte laranja ou mesmo vermelho. Nesse instante, não é surpreendente que as nuvens sem cores refletem os mesmos raios de uma maneira mais brilhante e viva? É observável que as nuvens não assumem comumente [p. 77] suas cores brilhantes até alguns minutos depois do sol e que elas passam do amarelo para uma cor flamejante dourada e disso, gradualmente, para vermelho, que se torna cada vez mais intenso, embora mais pálido, até que o sol junte-as todas. Agora, está claro que as nuvens recebem, nesse momento, a luz do sol através de um trecho de ar muito mais longo que nós no instante do pôr-do-sol, talvez pela diferente de cem milhas ou mais, como pode ser calculado de suas alturas ou da duração de suas cores. Portanto, não seria natural imaginar que, à medida que a luz do sol se torna sempre de alguma forma amarelada ou alaranjada ao passar horizontalmente através da espessura da atmosfera, ela deva se inclinar mais e mais do laranja para o vermelho, ao passar através de um comprimento ainda maior de ar, tal que as nuvens, de acordo com suas diferentes altitudes, possam assumir todas as variedades de cores nelas observadas no nascer e no pôr-do-sol, por simplesmente refletir a luz do sol incidente assim como elas a recebem? Quando estava na Suíça, observei com prazer que os picos nevados dos Alpes se tornam cada vez mais vermelhos depois do pôr-do-sol, da mesma maneira que as nuvens. O que faz [p. 78] as mesmas cores muitos mais ricas e abundantes nas nuvens são suas semi-transparências junto com a obliquidade nessas situações.

Isso não confirma enormemente essa explicação de que essas nuvens coloridas imediatamente reassumem aquela tonalidade escura de chumbo que elas recebem do céu assim que os raios diretos do sol param de atingi-las? Pois, se suas cores vistosas surgem, como aquelas de bolhas de sabão, de um tamanho particular de suas partes, elas preservariam muito proximamente as mesmas cores, embora muito mais fracas, quando iluminadas somente pela atmosfera. Ao pôr-do-sol ou um pouco depois, a parte mais baixa do céu, a alguma distância em cada lado de sua ocultação, parece tender a um fraco verde-mar, pela mistura de seus raios transmitidos, que são amarelados com um azul etéreo. A distâncias maiores, esse verde fraco muda gradualmente em um marrom avermelhado, porque os raios do sol, ao passar através de mais ar, começam a se inclinar para o laranja. E, do lado oposto do hemisfério, a cor do céu horizontal tende sensivelmente para o roxo, porque sua luz transmitida que se mistura com o azul-celeste, ao passar através de um comprimento ainda maior [p. 79] de ar, se torna avermelhado, como dissemos acima.

Para entender claramente por que os raios do sol mudam, ao passar através de uma quantidade cada vez maior de ar, gradualmente do branco ao amarelo, daí para o laranja e, por último, para o vermelho, temos apenas que aplicar à atmosfera o que Sir 
Isaac Newton (Livro I de seu Óptica, Parte 2, Proposição 10) [disse] acerca da cor dos líquidos transparentes em geral.

Não é a mesma luz colorida do nascer e do pôr-do-sol que pinta as nuvens que, sendo jogada pela refração da atmosfera na sombra da Terra, dá à lua algumas vezes, nos eclipses totais, a cor avermelhada obscura de tijolo? À medida que os raios que passam através do maior trecho de ar se tornam avermelhados, aqueles que passam através do menor, amarelados, e os intermediários, laranja; os vermelhos devem convergir mais rápido em sombra, depois deles, os laranjas e, por último, os amarelos, tal que todo o espaço da sombra da Terra, do ponto do cone à aproximadamente [ $]^{98}$ semidiâmetro da Terra, sendo preenchido com uma luz fraca, cujas cores beiram sempre mais para o vermelho ao aproximar da Terra. A cor da [p. 80] Lua, nos eclipses totais, deve necessariamente variar da mesma forma, de acordo com sua distância da Terra no momento da observação e, se eu não estiver errado, [deve] estar sempre mais inclinada ao vermelho ao entrar e sair da sombra, que no meio. Deixemos os astrônomos determinar se os fenômenos concordam com essa teoria. Não é surpreendente que essa luz refratada é muito fraca e escura na distância da Lua, uma vez que sua densidade média lá será sempre muito menor que a densidade da luz no pôr-do-sol, à medida que o espaço anular do ar mais abaixo através do qual ela passa, desenhada na paralaxe horizontal da luz, é menor que a área de um grande círculo da Terra desenhado em quatro vezes o excesso da refração horizontal da atmosfera acima da mesma paralaxe, que está talvez como 1 para [ ] ou mais.

QUESTÃO 16. Eu observei que, quando ao mar, embora eu pressionasse meu corpo e minha cabeça firmemente contra um canto da cabine, tal que ficasse em repouso em relação a cada objeto ao meu redor, os movimentos irregulares diferentes do navio eram, ao rolar e arfar, ainda discerníveis pela visão. Como esse fato pode ser conciliado com princípios ópticos? Devemos concluir que o olho, pelos movimentos repentinos do [p. 81] navio, é estendido de sua devida posição? Ou, se ele mantém uma situação fixa na cabeça, é a percepção do movimento do navio causada por uma vertigem no cérebro, uma ilusão da imaginação, ou qualquer outra causa?

QUESTÃo 17. O ouro não foi reduzido, ao ser batido, a um grau de espessura que excede um pouco aquele que deve ser atribuído às suas partes coloríficas, de acordo com a teoria de Sir Isaac Newton? Mas, como ele pode aderir a uma folha contínua, de modo a não deixar poros visíveis, a menos que haja muitas de suas partículas componentes contidas nessa espessura?

QUESTÃO 18. Quando alguém olha firmemente à Sirius ou qualquer estrela brilhante não muito elevada acima do horizonte, sua cor não parece ser constantemente branca, mas parece pintada, a cada piscada, alternadamente em vermelho e azul. A que se deve

98 [N.T.] Há um espaço em branco no texto original, ou seja, provavelmente Melvill não informou o valor. Mais à frente, há outro espaço em branco, possivelmente pelo mesmo motivo. 
esse evento? Não é a separação das cores pela refração da atmosfera muito pequena para ser percebida?

QUESTÃo 19. Corpos se tornam pretos pela combustão, porque eles são reduzidos ${ }^{99}$ a partes muito pequenas. Mas, por que motivo que [p. 82] a maioria dos corpos assumem, quando então queimados até cinzas, uma cor cinza ou esbranquiçada?

QUESTÃo 20. Já que a causa da pretidão em corpos é a pequenez de suas partes transparentes, que os tornam incapazes de refletir qualquer cor, como corpos pretos, sólidos ou fluidos, podem ser ao mesmo tempo opacos? Pode a luz ser finalmente extinguida pelos poderes refratores somente das partículas? Ou, [a luz] não deveria fazer seu caminho através do corpo, se não houvesse reflexão, sem qualquer perda sensível, embora vários raios pudessem sair em várias direções? E isso não pode ocorrer da mesma maneira em vários corpos opacos coloridos [?]. Como todos os tipos de luz podem ser paradas e extinguidas dentro de um corpo, cujas partes internas são feitas para refletir apenas uma ou duas cores, e transmitir o resto?

QUESTÃo 21. Se as partes e poros de corpos pelúcidos forem muito menores que o menor intervalo entre os estados de [fácil] reflexão e transmissão, está claro que os raios de luz entrando em uma parte ou poro em um estado de [fácil] transmissão, não serão refletidos em sua superfície posterior. E assim pode ser entendido como todos os raios que entram na primeira superfície de um corpo transparente continuam a ser transmitidos através de sua substância [p. 83] a grandes distâncias, ou seja, se os raios são sempre colocados em um novo estado de mais fácil transmissão ao entrar em cada novo poro ou partícula. Mas, essa suposição não é contrária àquela que Sir Isaac ensina em outro lugar, que os estados de [fácil] reflexão e transmissão continuam a retornar em intervalos iguais, depois de um raio ter entrado em um corpo transparente e são, assim, regularmente propagados a grandes distâncias? ${ }^{100} \mathrm{E}$, se isso for verdade, como os raios podem ser transmitidos a qualquer distância sensível, uma vez que eles devem chegar geralmente em estados de fácil reflexão nas superfícies comuns dos poros e partículas? Porém, embora possa ser entendido pela doutrina dos estados na luz porque não há reflexão a partir das partes interiores da água e de outros meios pelúcidos ${ }^{101}$, a transmissão retilínea da luz através desses corpos em todas as direções e, consequentemente, em todos os graus de obliquidades, às suas partes internas, não prova que essas partes, por conta de suas pequenezas, perdem seus poderes de refração assim como de reflexão? E a qual propriedade conhecida da luz ou dos corpos isso pode ser atribuído?

\footnotetext{
99 [M.] Óptica de Newton, Livro III [correto: Livro II], Parte 2, Proposição 7.

100 [M.] Óptica de Newton, Livro II, Parte 2, Proposição 12.

101 [M.] Óptica de Newton, Livro II, Parte 3, Proposição 4.
} 
[p. 84] QUESTÃo 22. Se os estados são produzidos por uma aceleração e retardamento alternados das partículas da luz, algumas das partículas que são rápidas o bastante para serem transmitidas na primeira superfície de um meio transparente, devem superar o poder refletor mais facilmente que outras, a saber, aquelas que estão em seus pontos de maior rapidez ou perto deles. Agora, os raios que estão se movendo com diferentes velocidades não devem ser diferentemente desviados de seus cursos pelo mesmo poder refrator, como argumentamos acima com respeito aos raios simples coloridos? Portanto, por que todo feixe de luz, homogêneo ou heterogêneo, não é dispersado pela refração em inúmeros raios, de acordo com as respectivas velocidades com as quais eles entram na superfície refratora? Isso não é uma resposta suficiente para essa questão, de que os raios que estão mais longe de seus pontos de maior velocidade serão mais desviados em uma direção contrária àquela da refração, pelo poder refletor e, assim, retornarão somente na direção dos raios mais rápidos por um grau maior de refração?

QUESTÃo 23. Sir Isaac Newton argumenta legitimamente que a luz deve ser refletida a uma distância dos corpos, visto que as mais polidas [p. 85] superfícies, sendo extremamente ásperas e irregulares em relação às partículas de luz, as dispersariam indiferentemente em todas as direções, se elas ressoassem delas por se chocar. Porém, uma dificuldade parecida não permaneceria, ou seja, como a luz pode ser refletida ou refratada regularmente pela superfície mais bem polida, se o poder do corpo procede de uma atração ou repulsão pertencente a cada ponto físico? Se talvez fosse suposto que o poder repulsivo do corpo produz reflexão a uma distância tão grande, em relação às desigualdades que restam nos corpos polidos, que a direção da força, resultante de suas ações conjuntas, pode ser muito proximamente perpendicular à superfície geral do corpo, e isso explicará a reflexão regular da superfície anterior de um meio denso. Mas, essa suposição será suficiente para explicar a regularidade da refração e da reflexão a partir da superfície posterior de um meio denso [?]. Em ambos os casos, a luz deve, na verdade, entrar nos poros do corpo atrator e, portanto, chegar muito mais perto de uma desigualdade que de outra, já que os poros pelos quais ela entra são certamente muito menores que aquelas desigualdades. $\mathrm{Na}$ [p. 86] água e em outros líquidos transparentes, esse deve ser certamente o caso, se suas partículas globulares tocam umas às outras, como é comumente concluído de suas incompressibilidades. Pois, conforme um número de esferas colocadas juntas não deixa passagens retilíneas entre elas, a luz transmitida deve passar através das partículas componentes e, dessa forma, os poros, pelos quais ela entra, devem ser muito menores que todas as superfícies hemisféricas das partículas que evidentemente constituem as desigualdades da superfície geral do líquido ${ }^{102}$.

102 [M.] Temos certeza que as desigualdades de uma rocha escarpada ou um muro irregular são muito maiores que as partículas de ar ou suas distâncias uma da outra, pelas quais seus poderes repulsivos são provavelmente 
QUESTÃo 24. Como a luz preserva seu curso retilíneo ao passar através do ar, do éter e de outros fluidos elásticos? A dificuldade ainda não continuaria, qualquer que fosse a sutileza ou raridade atribuída a esses meios, uma vez que os poderes de onde suas elasticidades surgem devem prevalecer através de todos os espaços livres que ficam entre suas partículas? Não devemos supor, dessa forma, que os raios de luz não estão [p. 87] sujeitos a esses poderes repulsivos, apesar de eles passarem através da esfera de suas ações? A refração da luz em direção à perpendicular, saindo dos espaços celestes para o ar, não prova que ela é atraída pelas partículas de ar? Não seria extravagante e incongruente além da conta pensar o éter tão sutil em relação à luz que, embora ele seja expelido do caminho pelos raios, como o ar é pelos projéteis comuns, não seja capaz de retardá-los sensivelmente em seus movimentos das mais distantes estrelas fixas até nosso olho? Essas e outras muitas dificuldades na parte física da Óptica, cuja solução é procurada em vão por quaisquer princípios já descobertos, não mostram a necessidade de estender nossas visões e aumentar nosso estoque de princípios por outras investigações experimentais? Tais objeções não devem ser consideradas como demonstrações da falsidade da nossa atual teoria, mas como provas de sua limitação, parcialidade e imperfeição.

Descartes, se contentando com um conhecimento superficial e incorreto das leis de impulso, sonhou em vão que ele tinha obtido a causa universal [p. 88] de onde todos os efeitos da Natureza são derivados, quando, na realidade, ele foi incapaz de deduzir deles os casos mais simples de colisão. Muitos nessa época que escrevem e especulam sobre assuntos físicos parecem cair em erro semelhante. Enquanto eles empregam todos seus estudos no esforço de reconciliar todos os fenômenos com os novos princípios descobertos por Sir Isaac Newton e, quando eles encontram, para seu tormento, que isso nem sempre tem êxito, os fenômenos devem ser disfarçados e a Natureza torturada para esconder suas ignorâncias. Do método preguiçoso de filosofar no armário, entre livros e diagramas, nunca surge [e] nunca surgirá qualquer descoberta como consequência. Grandes inventores usualmente entendem muito bem a extensão de seus próprios princípios, para deixar muito de suas aplicações para outros ${ }^{103}$.

A descoberta da diferente refrangibilidade dos raios foi uma inestimável adição ao conhecimento natural, à medida que ela serve, de uma vez só, para explicar inumeráveis fenômenos na Natureza que fluem dela como consequências imediatas e necessárias. Se for demonstrado pela observação proposta no item 49 que os raios

terminados (Principia de Newton). Por que é observado, então, refletido tão regularmente de tais corpos que o eco é ouvido fracamente, exceto em um ângulo incidente igual ao ângulo de reflexão?

103 [N.T.] Nesse ponto, cabe ressaltar como os comentários de Melvill divergiram daqueles da maioria dos filósofos naturais defensores de Newton no século XVIII. Enquanto esses últimos sempre elogiavam Newton e a perfeição de suas ideias, Melvill salientou como ela ainda era imperfeita e que muito havia por ser determinado e discutido. 
coloridos diferentemente [p. 89] realmente se movem com velocidades diferentes, nossa teoria da luz seria ainda mais aperfeiçoada, já que a diferente refrangibilidade pode ser assim mecanicamente explicada.

Todo o sistema da Natureza é uma imensa série de causas e efeitos, cujo começo e fim estão igualmente escondidos nas profundezas na infinitude. Apenas uma pequena, uma pequenina porção dele aparece sob nossa observação imediata, sendo exposto à visão e a outros sentidos de toda humanidade. Quase todo fenômeno é, de uma vez, a causa de múltiplos efeitos, e um efeito, dentre muitos, de uma causa superior. $\mathrm{O}$ trabalho da Ciência é estender nossas visões ao revelar as causas ocultas que existem na Natureza, e disso explicar os efeitos manifestos. A descoberta de uma tal causa real, desconhecida antes, se ela for de influência geral ou muito extensiva, como a da gravitação universal, é para ser valorizada como um grande avanço da filosofia natural. Desvalorizar tal descoberta, como alguns têm feito, porque a causa daquela causa não pode ser ainda atribuída, é altamente absurdo ${ }^{104}$, visto que a mesma objeção deve para sempre estar contra [p. 90] todas as causas, exceto as primárias, que são certamente removidas bem longe do alcance da investigação humana. O adequado ofício e o mais alto motivo de orgulho da verdadeira filosofia é nos trazer para ainda mais perto da Deidade, ao nos levar para cima, passo a passo, para a poderosa camada da Natureza.

\section{Agradecimentos}

$\mathrm{O}$ autor agradece o apoio financeiro da Fundação de Amparo à Pesquisa do Estado de São Paulo (FAPESP, processo $\mathrm{n}^{\mathrm{o}}$ 2014/04366-2) e do Conselho Nacional de Desenvolvimento Científico e Tecnológico (CNPq, processo $n^{\circ} 400118 / 2016-5$ ) para a realização das pesquisas que originaram este artigo.

\section{Referências bibliográficas}

ADDISON, W. I. The matriculation albums of the University of Glasgow from 1728 to 1858. Glasgow: James Maclehose and Sons, 1913.

BRADLEY, J. Miscellaneous works and correspondence of the Rev. James Bradley, D.D.F.R.S. Oxford: Oxford University Press, 1832.

CANTOR, G. N. Optics after Newton - theories of light in Britain and Ireland, 17041840. Manchester: Manchester University Press, 1983.

104 [N.T.] A causa da gravitação foi um ponto polêmico da mecânica newtoniana por várias décadas após a publicação dos Principia. Para mais detalhes, ver Harper (2002). 
CLERKE, A. M. "Melvill, Thomas (1726-1753)”. In: MATTHEW, H.C.G.; HARRISON, B. (eds.). Oxford Dictionary of National Biography. Online ed. Oxford: Oxford University Press, 2004. Disponível em: <http://www.oxforddnb.com/view/article/18542>. Acesso em: 13 mai. 2020.

COHEN, I. B. Benjamin Franklin's Science. Cambridge-MA: Harvard University Press, 1990.

COHEN, I. B.; SCHOFIELD, R. Isaac Newton's Papers and Letters on Natural Philosophy and related documents. Cambridge-MA: Harvard University Press, 1958.

DARRIGOL, O. A history of optics from Greek Antiquity to the Nineteenth Century. Oxford: Oxford University Press, 2012.

EKLUND, J. The incompleat chymist: being an essay on the eighteenth century chemist in his laboratory, with a dictionary of obsolete chemical terms of the period. Washington: Smithsonian Institution Press, 1975.

EMERSON, R. L. The Philosophical Society of Edinburgh 1748-1768. The British Journal for the History of Science, v. 14, n. 2, p. 133-176, 1981.

GUZZARDI, L. Ruggiero Boscovich and "the Forces existing in Nature". Science in Context, v. 30, n. 4, p. 385-422, 2017.

HAKFOORT, C. Optics in the age of Euler - conceptions of the nature of light, 17001795. Cambridge: Cambridge University Press, 1995.

HARPER, W. Newton's arguments for universal gravitation. In: COHEN, I. B.; SMITH, G. E. (Eds.). The Cambridge Companion to Newton. Cambridge: Cambridge University Press, 2002. p. 174-201.

HUTTON, C. A mathematical and philosophical dictionary. v. 2. London: J. Johnson, 1795.

LE GOFF, J. Por uma outra Idade Média: tempo, trabalho e cultura no Ocidente. 3. ed. Petrópolis: Vozes, 2014.

MARTINS, A. F. P. Natureza da Ciência no ensino de ciências: uma proposta baseada em “temas" e "questões". Caderno Brasileiro de Ensino de Física, v. 32, n. 3, p. 703-737, 2015. 
MARTINS, R. A. A maçã de Newton: história, lendas e tolices. In: SILVA, C.C. (ed.). Estudos em História e Filosofia das Ciências: subsídios para aplicação no ensino. São Paulo: Livraria da Física, 2006. p. 167-189.

MARTINS, R. A. Tratado sobre a luz. Caderno de História e Filosofia da Ciência, suplemento 4, p. 3-99, 1986.

MELVILL, T. A letter from Mr. T. Melvill to the Rev. James Bradley, D.D.F.R.S. With a discourse concerning the cause of different refrangibility of the rays of light. Philosophical Transactions (1683-1775), v. 48, p. 261-270, 1753-1754.

MELVILL, T. Observations on light and colours. Essays and Observations, Physical and Literary read before a society in Edinburgh and published by them, v. 2, p. 12-90, 1756.

MOURA, B. A. Isaac Newton e a dupla refração da luz. Revista Brasileira de Ensino de Física, v. 36, n. 4, artigo $\mathrm{n}^{\circ}$ 4602, 2014.

MOURA, B. A. Newton versus Huygens: como (não) ocorreu a disputa entre suas teorias para a luz. Caderno Brasileiro de Ensino de Física, v. 33, n. 1, p. 111-141, 2016.

MOURA, B. A. Newtonian optics and the historiography of light in the $18^{\text {th }}$ century: a critical analysis of Joseph Priestley's The History of Optics. Transversal - International Journal for the Historiography of Science, n. 5, p. 157-170, 2018.

MOURA, B. A. A filosofia natural de Benjamin Franklin: traduções de cartas e ensaios sobre a eletricidade e a luz. São Bernardo do Campo: EdUFABC, 2019.

MOURA, B. A. The problem of reflection in eighteenth-century projectile theories of light. Physics in Perspective, no prelo.

MOURA, B. A.; SILVA, C. C. A teoria dos estados da luz: considerações sobre o papel das hipóteses na óptica newtoniana. In: MARTINS, R. A. et al. Filosofia e História da Ciência no cone Sul: seleção dos trabalhos do $5^{\circ}$ encontro. Campinas: Associação de Filosofia e História da Ciência do Cone Sul, 2008.

MOURA, B. A.; SILVA, C. C. Forças entre luz e matéria: modelos mecânicos da óptica corpuscular no início do século XVIII. In: MARTINS, R. A.; LEWOWICZ, L.; FERREIRA, J. M. H.; SILVA, C. C.; MARTINS, L. A. C. P. Filosofia e história da ciência no cone sulseleção de trabalhos do $6^{\circ}$ encontro. Campinas: Associação de Filosofia e História da Ciência do Cone Sul, 2010. 
NEWTON, I. Óptica. São Paulo: EDUSP, 1996.

NEWTON, I. The Mathematical Principles of Natural Philosophy. New York: Daniel Adee, 1848.

NICHOLSON, W. The British Encyclopedia. v. 5. London: C. Whittingham, 1809.

NORTH, J. D. "Melvill, Thomas". In: GILlISPIE, C. C. (Ed.). Dictionary of Scientific Biography. v. 9. New York: Charles Scribner's Sons, 1981. p. 266-267.

OUSTINOFF, M. Tradução: história, teorias e métodos. São Paulo: Parábola Editorial, 2011.

RICCEUR, P. Sobre a tradução. Belo Horizonte: Editora UFMG, 2011.

ROBISON, J. “Optics”. In: Encyclopædia Britannica. v. 13. $3^{\text {rd }}$ ed. Edinburgh: A. Bell and C. Macfarquhar, 1797.

SCHIEBINGER, L. The philosopher's beard: women and gender in science. In: PORTER, R. (Ed.). The Cambridge History of Science. v. 4 (The eighteenth century). Cambridge: Cambridge University Press, 2008. p. 184-210.

SILVA, C. C.; MARTINS, R. A. A "Nova teoria sobre luz e cores" de Isaac Newton: uma tradução comentada. Revista Brasileira de Ensino de Física, v. 18, n. 4, p. 313-27, 1996.

STEFFENS, H. The development of Newtonian optics in England. New York: Science History Publications/USA, 1977.

SUTTON, M.A. Sir John Herschel and the development of spectroscopy in Britain. The British Journal for the History of Science, v. 7, n. 1, p. 42-60, 1974.

WHITEHEAD, B.J. (Ed.). Women's education in Early Modern Europe: a history, 15001800. New York/London: Garland Publishing, Inc., 1999.

WILSON, P. Biographical account of Alexander Wilson, M.D. late professor of practical astronomy in Glasgow. By the late Patrick Wilson, A. M. Professor of Practical Astronomy in the University of Glasgow. The Edinburgh Journal of Science, v. 10, p. 1-17, 1829.

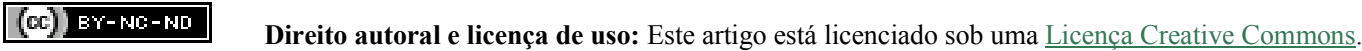

